\title{
In Defense of Resident Hiring Preferences: A Public Spending Exception to the Privileges and Immunities Clause
}

\author{
Patrick Sullivan $\dagger$
}

This Comment analyzes the legal hurdles that cities must overcome when they attempt to mandate resident hiring preferences on public works construction projects. It begins by noting an emerging doctrinal inconsistency in the way courts review these local resident preference plans. Specifically, it observes that cities have been able to overcome challenges brought under the Dormant Commerce Clause by appealing to a market participant exception, while they have not been able to invoke an analogous defense to fend off challenges brought pursuant to the Privileges and Immunities Clause.

In analyzing this inconsistency, this Comment argues that there is no principled reason for the different treatment the two types of claims receive, given that both Clauses were motivated by similar principles of interstate comity and economic unity. This Comment argues further that there can and should be a public spending exception to the Privileges and Immunities Clause, similar to the Dormant Commerce Clause's market participant exception. The exception would exempt cities from the Privileges and Immunity Clause's purview when those cities place local resident hiring requirements on jobs funded with public money. Such an exception would be consistent with the underlying principles of the Clause, would respond to the particular contours of current Privileges and Immunities doctrine. Further, an exception would allow cities to adopt commonly employed preference plans, which plans cities rely on to address many pressing social problems.

Copyright ( 1998 California Law Review, Inc.

$\dagger$ J.D. Candidate 1999, Boalt Hall School of Law, University of California, Berkeley; M.P.A. Candidate 1999, Woodrow Wilson School, Princeton University. I wish to thank Professor Daniel Rodriguez and Julian Gross for their helpful comments on earlier drafts of this Comment. 


\section{INTRODUCTION}

American cities collectively spend over $\$ 700$ billion each year purchasing goods and services, paying salaries, and building public infrastructure. In 1994, local governments spent over $\$ 60$ billion on construction projects alone. ${ }^{1}$ A city may want to ensure that some of this money goes to local residents in the form of jobs and public contracts. This Comment seeks to answer the question of whether cities should be able to implement such preferences.

A city has several options in accomplishing its goal of finding jobs for local residents on public works and other projects. A city could change its own hiring policies. In addition, it could go a step further and impose local hiring requirements on the private employers with whom the city contracts for construction and other public projects. These requirements could take a number of forms: the city could mandate that contractors hire a fixed percentage of local workers, that they use local workers as a "first source" for hiring, or simply that they use a government-iun einployee referral service. ${ }^{2}$ Procedurally, cities typically enact these preference programs either through legislative ordinances, executive orders, or private contracts negotiated with individual contractors. ${ }^{3}$

Of course, hiring residents means not hiring nonresidents, which potentially gives rise to constitutional concerns. Trade union members and other workers not hired due to local hiring programs have brought challenges against several cities under several constitutional provisions, including the Equal Protection Clause, the Commerce Clause, and the Privileges and Immunities Clause. This Comment analyzes the Privileges and Immunities challenges, and argues that local preference plans should withstand this constitutional scrutiny. ${ }^{4}$

1. See U.S. Bureau of the Census, U.S. State and Local Government Finance Estimates, 1993-1994 (last modified April 14, 1997) <http://www.census.gov/ftp/pub/govs/ www/index.html>. For fiscal year 1993-1994, direct expenditures by local governments, excluding intergovernmental transfers, totaled $\$ 710,365,559,000$. See id. Construction expenditures totalcd $\$ 60,342,676,000$. See id.

2. See Stephanie Haffner, National Economic Development \& Law Center, Using local hiring Programs to Promote Employment Opportunities in Low-Income Communities: Examples and Practical Considerations (1996).

3. See id. at 7 .

4. In addition to mandating preferences in contracting, inany citics also give local rcsident preferences in their direct hiring, or place residency requireinents on various public sector jobs such as that of a firefighter and police officer. Courts generally find these prefcrences in dircct hiring less constitutionally suspect than the local hiring requirements placed upon private cinployers with city contracts. See infra notes 101-118 and accompanying text. Accordingly, this Comment focuses primarily on the more controversial practice of granting contracting preferences. 


\section{A. The Constitutional Framework}

The Privileges and Immunities Clause of the U.S. Constitution provides that "[ $t]$ he Citizens of each State shall be entitled to all Privileges and Immunities of Citizens in the several States." It was designed to prevent individual states from enacting tariffs and regulations that would inpede the free flow of commerce throughout the nation. ${ }^{6} \mathrm{Ac}$ cordingly, the U.S. Supreme Court generally views local preferences as an unlawful form of discrimination against nonresidents, and approves the plans only in rare cases. ${ }^{7}$ With its anti-protectionist motive, the Privileges and Immunities Clause is a close cousin to the Commerce Clause, which gives Congress the exclusive authority to "regulate Commerce... among the several states." The Commerce Clause, specifically its "dormant" implications, has been interpreted to deny individual States the power to impose burdens on interstate commerce. ${ }^{9}$ Similarly, the Court has repeatedly asserted that the ability to pursue one's economic livelihood irrespective of state boundaries is essential to the values of "interstate comity" and national economic unity that underlie the Privileges and Immunities and Dormant Commerce Clauses. ${ }^{10}$ Another barrier to interstate discrimination is the Equal Protection Clause, which provides that "[n]o State shall ... deny to any person within its jurisdiction the equal protection of the laws."

5. U.S. CoNsT. art. IV, $\S 2$, cl. 1. This Comment is primarily concerned with cities. The Privileges and Immunities Clause of course speaks in terms of state citizenship. See id. While this wording may seem to mean that cities escape the strictures of the Clause, the Supreme Court has cleared up any confusion on this matter, and has held that the Clause indeed does apply to cities. See United Bldg. \& Constr. Trades Council v. Mayor of Camden, 465 U.S. 208, 214 (1984) (rejecting a New Jersey Supreme Court ruling that the Clause does not apply to municipal ordinances). A potential Privileges and Immunities violation by a city is therefore legally equivalent to a violation by a State. Thus, an analysis of the city's violation will mirror such an analysis for a State. See id. at 216-17 (noting that "whether the exercise of a privilege is conditioned on state residency or on municipal residency, [a person who is not residing in a given State] will just as surely be excluded"). As such, except when relevant to the discussion, this Comment will use the terms "State" and "city" interchangeably when discussing discrimination for Privileges and Immunities purposes.

6. See, e.g., Supreme Court of New Hampshire v. Piper, 470 U.S. 274, 279-80 (1985) ("[T]he Privileges and Immunities Clause was intended to create a national economic union.").

7. See, e.g., Umited Bldg. \& Constr. Trades Council v. Mayor of Camden, 465 U.S. at 222-23 (1984) (remanding for findings as to the city's "grave economic and social ills").

8. U.S. CONST. art. I, $\S 8$, cl. 3.

9. See, e.g., New Energy Co. v. Limbach, 486 U.S. 269, 273 (1988) ("It has long been accepted that the Commerce Clause not only grants Congress the authority to regulate commerce among the states, but also directly limits the power of the states to discriminate against interstate commerce.").

10. See, e.g., Toomer v. Witsell, 334 U.S. 385, 396 (1948) ("[O]ne of the privileges which the Clause guarantees to citizens of State A is that of doing business in State B on terms of substantial equality with the citizens of that State."); Salla v. County of Monroe, 399 N.E.2d 909, 915 (N.Y. 1979) (" $[\mathrm{A}]$ potentially absolute barrier to out-of-State public works contractors ... is in conflict with the national policy of economic unity.").

11. U.S. ConsT. amend. XIV, $\$ 1$. 
comply with this stricture as well if it wishes to favor local residents and businesses. $^{12}$

Despite this overarching concern with economic unity, the Court does not analyze local preference ordinances under the relevant constitutional theories-Equal Protection, the Dormant Commerce Clause, and the Privileges and Immunities Clause-in the saine way. In fact, these different analyses often produce different judicial outcomes. ${ }^{13}$ Although cities enacting local preference programs have found ways to withstand Dormant Commerce Clause and Equal Protection challenges, ${ }^{14}$ the Privileges and Immunities Clause remains an insurmountable obstacle for many cities that atteinpt resident preference ordinances.

The discrepancy in the application of the constitutional theories is nost evident in the different treatment that cities receive under the Dormant Commerce Clause and the Privileges and Immunities Clause when they act as market participants or as proprietors spending their own funds. Indeed, a doctrinal inconsistency seems to exist, whereby an identical local preference plan will enjoy broad market participant iminunity under the Dormant Commerce Clause but not under the Privileges and Immunities Clause. This Comment explores the reason for this difference and argues that the core feature of market participation-government spending its own money-should support an exception to the Privileges and Immunities Clause for a city or State. Further, this Comment also explores the unanswered doctrinal question of whether a city inay favor its residents in the expenditure of funds that are not its own, nainely federal or state funds often utilized in city public works projects.

12. See Int'l Org. of Masters, Mates \& Pilots v. Andrews, 626 F. Supp. 1271, 1278 (D. Alaska 1986) (wherein plaintiff challenged differential wage policy on Equal Protection grounds).

13. Compare United Bldg. \& Constr. Trades Council v. Mayor of Camden, 465 U.S. 208, 208 (1984) (finding a potential Privileges and Immunities violation in a city ordinance which required that at least $40 \%$ of the employees of contractors and subcontraetors working on city construction projects be city residents), with White v. Massachusetts Council of Constr. Employers, Inc., 460 U.S. 204 (1983) (finding no Dormant Commerce Clause violation in a city ordinance which required that all construction projects funded with city funds be performed by a workforce consisting of at least $50 \%$ city residents).

14. Under Equal Protection doctrine, state residency is not a "suspect classification" such that it would trigger strict scrutiny review. See, e.g., Laborers Local Union No. 374 v. Felton Constr. Co., 654 P.2d 67, 72 (1982). Accordingly, cities may enact resident preferences without violating the Fourteenth Amendment as long as the preferences are rationally related to a legitimate state interest, such as alleviating local unemployment. See, e.g., Camden, 465 U.S. at 213 (noting that the city of Camden had rendered moot the equal protection challenge against it by removing a one-year residency requirement from its local hiring ordinance, and instead simply granting preferencc to all residents; thus, no equal protection violation in these resident preferences). Under the Dormant Commerce Clause, a city can impose local hiring requirements when it acts as a "market participant" or as a proprietor spending its own funds. See, e.g., Camden, 465 U.S. at 213; White, 460 U.S. at 214-15. 
Creating an exception to the Privileges and Immunities Clause when cities are spending their own funds would allow many cities greater latitude to address local economic realities. The burden of data production required to meet the Court's current Privileges and Immunities test is itself daunting for many cities, and dissuades them either from defending in court what might be a perfectly legal plan, or from even atteinpting to design such a plan in the first place. ${ }^{15}$ As this Comment explains, there is a firm theoretical basis for allowing cities to enact these preference plans, and in addition, they need not implicate the concerns with preserving a national economic union that underlie the Privileges and Immunities Clause.

\section{B. Why We Should Care}

Understanding the constitutional challenges that governmental entities face when enacting these local preference statutes is important for several reasons. The first is the sheer number and extent of such statutes. Nearly half the States have some form of local preference statute, ${ }^{16}$ and a vast number of cities operate preference programs as well. ${ }^{17}$ These programs may be popular because they satisfy the common sense belief that public expenditures should benefit the citizens who contribute the revenue. More broadly, the programs nay be seen as a way to force companies to "give back" to the community some of the benefit they derive from the award of city contracts. ${ }^{18}$

Second, local preference statutes will likely continue to be popular because they are perceived to hold large development potential for economically distressed cities. Public works projects benefit a city not only by creating a building, freeway, stadium, or other infrastructure, but also by providing construction-related employment during the project. ${ }^{19}$ While there are no einpirical estimates of the true impact of resident preference plans on local economies, cities facing high unemployment, chronic poverty, and severe disinvestınent by private enterprise could

15. Telephone Interview with Julian Gross, Staff Attorney, Legal Aid Society of San Francisco, Employment Law Center (May 15, 1997); see also infra notes 57-62 and accompanying text.

16. See Thomas H. Day, Note, Hiring Preferences Acts: Has the Supreme Court Rendered Them Violations of the Privileges and Immunities Clause?, 54 FORDHAM L REv. 271, 272 \& n.13 (1985) (citing statutes in 22 states that mandate or authorize local hiring preferences).

17. See HAFFNER, supra note 2, at 8 (analyzing local hiring laws in a sample of ten cities, including Berkeley, CA, Boston, MA, Chicago, IL, Marin City, CA, Miami, FL, Minneapolis, MN, Oakland, CA, San Antomo, TX, San Francisco, CA, and Washington, D.C.).

18. See id. at 3.

19. See Paul K. Sonn, Note, Fighting Minority Underrepresentation in Publicly Funded Construction Projects after Croson: A Title VI Litigation Strategy, 101 YALE LJ. 1577, 1584 (1992) ("[An] important social good flowing from public works spending is the creation of jobs for construction workers. By selecting a particular contractor for a job, a state in effect selects a group of workers to benefit from that public project."). 
view these public works projects as an important source of construction jobs for an increasingly underemployed blue collar workforce. ${ }^{20}$ However, these benefits accrue to a city only if the city can target these construction jobs to residents in need. Thus, economically distressed cities will be specially motivated not to squander on nonresidents the economic development potential of their public works expenditures.

Finally, local preferences may take on an increased importance as an economic development tool following the recent retrenchment on affirmative action by the U.S. Supreme Court. By its rulings in City of Richmond v. J.A. Croson Co. ${ }^{21}$ and Adarand Constructors, Inc. v. $P e \tilde{n} a{ }^{22}$ the Supreine Court subjects all city, state, and federal race-based affirmative action programs to strict judicial scrutiny. Accordingly, government at all levels both must overcome difficult hurdles in order to justify and operate affirmative action programs and must deal with an increased risk of lawsuits given the growing hostility to affirmative action. Indeed, the recent passage of Proposition 209 in California, which bans all racial "preferences" by city and state governments, portends even greater scrutiny in years to come. ${ }^{23}$ Accordingly, cities that previously looked to minority hiring and contracting requirements as a means to increase employment of local people of color will now find these goals difficult or impossible to meet directly. Cities with a high proportion of residents who are people of color may be able to meet these same goals through the use of local preference requirements. ${ }^{24}$ While local preference plans are not a substitute for affirmative action plans that directly target women and people of color, cities in the

20. See, e.g., George T. Reynolds, Constitutional Law-Constitutional Assessment of State and Municipal Residential Hiring Preferences Laws, 40 ViLL. L. REv. 803, 803 (1995) ("These laws are generally intended to alleviate local unemployment and funnel local resources back to the constituents of the enacting authority."); Werner Z. Hirsch, An Economic Analysis of the Constitutionality of State Preference Laws, 14 INT'L REv. L. \& ECON. 299, 301 (1994) (arguing that "[e]mployment and tax benefits are assumed to be the major benefits for a government pondering [a resident preference law]," and that "[e]mployment benefits for a given level of public works construction will be higher if more workers are taken from the ranks of the previously unemployed").

21. 488 U.S. 469 (1989).

22. 515 U.S. 200 (1995).

23. See CAL. Const. art. I, § 31 .

24. Indecd, the local preference requirements at issue in United Bldg. \& Constr. Trades Council v. Mayor of Camden, 465 U.S. 208 (1984), a seminal case in this area, were part of a larger hiring ordinance passed by the city that included race-based affirmative action requirements for city contractors. Id. at 210-11. Presumably, the new, more hostile legal cnvironment for affirmative action would enable the Camden plaintiffs today to challenge not only the local resident preferences, but also the raee-based hiring preferences. Many other cities including Boston, Massachusetts, have 0included local preferences in the same ordinances and agreements as race- and gender-bascd affirmative action requirements. See HAFFNER, supra note 2, at 2 n.3. 
post-affirmative action world may look to resident preferences to bear a larger proportion of their economic development needs. ${ }^{25}$

Part I of this Comment will look at the current status of Privileges and Immunities doctrine and at the Court's current Privileges and Immunities test. Part II discusses the market participant exception to the Dormant Commerce Clause and explains that no analogous exception exists under the Privileges and Immunities Clause. Part II then discusses how an analogous public spending exception could be justified. The exception would provide the same categorical immunity under the Privileges and Immunities Clause as the market participation exception provides under the Dormant Commerce Clause. Part II also addresses many of the criticisms of the market participant exception and argues that these criticisms are not as relevant to a public spending exception to the Privileges and Immunities Clause. Finally, Part II addresses the important question of whether the common use of federal funds on local public works projects would undermine a city's ability to claim this public spending exception. As a whole, this Comment seeks to establish a rationale for a public spending exception to the Privileges and Immunities Clause.

\section{I}

\section{The Privileges and Immunties Test}

Do cities and States consider the Privileges and Immunities Clause when writing their local hiring ordimances? The City of Oakland, California, writes im the preamble to its Local Employment Program ordinance:

In order to counteract grave economic and social ills, and spiraling unemployment; and to increase the number of employed persons living im Oakland; all of which is in substantial degree caused by the influx of non-Oakland residents; the city of Oakland establishes this carefully and narrowly tailored [program] without unreasonably harming non-residents. ${ }^{26}$

In a similar vein, the City of East Palo Alto, California, in its First Source Hiring Policy, speaks of the city's high unemployment and underdevelopment, and asserts that "[C]ity-owned public works

25. This shift could be particularly pronounced in California due to the recent passage of Proposition 209. Note, however, that a city's use of resident preferences might still trigger court scrutiny under Croson if the city attempted to introduce a residency classification as a clear proxy for race. See Personnel Adm'r of Mass. v. Fceney, 442 U.S. 256, 272 (1979) ("A racial classification $\ldots$ is presumptively invalid and can be upheld only upon an extraordinary justification .... This rule applies as well to a classification that is ostensibly neutral but is an obvious pretext for racial discrimination.").

26. City of OAKland and Redevelopment Agency, Local Employment Program for PUBLIC WORKS CONTRACTS 1 (revised 1995). 
construction projects are an important source of ... employment opportunities within the City for qualified residents." Further,

[t]he overwhelming majority of employment on past Cityowned public works projects has gone to nonresidents of the City, and thus that nonresident employment on City-owned public works projects is a peculiar evil that substantially diminishes the ability of these projects to mitigate unemployment in the City. ${ }^{27}$

What motivates these statements of purpose, with their mention of an "imflux of nonresidents" and a "peculiar evil"? As this Part will explain, these ordinances respond to the particular contours of the Privileges and Immunities Clause. ${ }^{28}$

\section{A. The Court's Current Test}

The U.S. Supreme Court's modern Privileges and Immunities doctrine emerged in 1948 with Toomer $v$. Witsell. ${ }^{29}$ The two-part test enunciated in that case, despite recent refinements, remains in use. This test asks (1) whether the offending city or State has violated a right that is fundamental to national unity, and (2) whether the city or state had a substantial reason for doing so. ${ }^{30}$ It is evident from this test that rights under the Privileges and Immunities Clause are not absolute. Nevertheless, the doctrine has been interpreted in different ways by different courts, in practice limiting the operation of local contracting preferences.

Many of the earlier Privileges and Immunities cases of the last century were concerned with determining what rights were fundamental, and thus protected by the Privileges and Immunities Clause. The Court's inquiry usually stopped there. In Paul $v$. Virginia, ${ }^{31}$ the Court identified the original purpose of the Privileges and Immunities Clause as fostering national union by prohibiting discrimination on the basis of state citizenship. The Court went on to hold that only those fundamental rights of citizens "as citizens" are important to the national union; mere special privileges granted by a State to its residents are not. ${ }^{32}$ Paul did little,

27. City of East Palo Alto, first Source Hiring Policy for City Public Works Construction Projects 1 (1994).

28. Of course, wording alone will not render a city's action constitutionally valid. Courts will scrutinize local hiring plans for actual findings of resident unemployment and lahor market conditions. See, e.g., W.C.M. Window Co., Inc. v. Bernardi, 730 F.2d 486, 497-98 (7th Cir. 1984) (finding Illinois preference law invalid because of a lack of statistical or other evidence demonstrating the costs and benefits of the law).

29. 334 U.S. 385 (1948).

30. See id. at 395-96.

31. See 75 U.S. (8 Wall.) 168,180 (1868).

32. See id. 
however, to clarify this line between fundamental rights and special privileges, a line that remains unclear to this day.

Courts in these early cases generally agreed that the most important of the fundamental rights of citizens "as citizens" was the "right" to engage in commerce, trade, or business. ${ }^{33}$ In Ward $v$. Maryland ${ }^{34}$ for example, the Court overturned a Maryland statute that prohibited nonresidents of the State from selling goods within the State, unless those goods were manufactured within Maryland. The Court held that the Privileges and Immunities Clause "plainly and unmistakably secures and protects the right of a citizen of one State to pass into any other State of the Union for the purpose of engaging in lawful commerce, trade, or business without molestation. ${ }^{35}$ However, in McCready v. Virginia ${ }^{36}$ the Court ruled that access to a State's oyster beds by commercial fishermen did not constitute a fundamental right, so that denying access to these beds to out-of-state fishermen did not amount to a Privileges and Immunities violation. ${ }^{37}$ Despite the commercial character of the activity in $\mathrm{McCready}$, this activity did not warrant Privileges and Immunities protection. Thus, the simplicity of the early Privileges and Immunities test did not ensure consistent results because the line between fundamental rights and special privileges was highly indeterminate.

Toomer $v$. Witsell ${ }^{8}$ heralded the modern expression of Privileges and Immunities jurisprudence. Toomer differs from earlier cases in that it allows courts to balance the State's interests in discrimination with the harm suffered by claimants. In addition to inquirmg whether a State has violated a fundamental right, Toomer also asks whether the State has "substantial reasons" for its discrimination against nonresidents and whether the degree of discrimination bears a close relation to these reasons. ${ }^{39}$ This test is rather stringent because the Court rephrases it to say that "the purpose of [the Privileges and Immunities Clause] ... is to outlaw classifications based on the fact of non-citizenship unless there is something to indicate that non-citizens constitute a peculiar source of the evil at which the statute is aimed." ${ }^{40}$ Thus, in Toomer the Court ruled that a South Carolina statute that made commercial shrimp fishing significantly more difficult and expensive for nonresidents, for no substantial reason other than blatant discrimination, violated the Privileges and

33. See, e.g., Ward v. Maryland, 79 U.S. (12 Wall.) 418, 430 (1870); see also Mark P. Gergen, The Selfish State and the Market, 66 TEx. L. REv. 1097, 1116 (1988).

34. 79 U.S. (12 Wall.) 418 (1870).

35. Id. at 430.

36. 94 U.S. 391 (1876).

37. See id. at 396 .

38. 334 U.S. 385 (1948).

39. See id. at 396.

40. Id. at 398 (emphasis added). 
Immunities Clause. ${ }^{41}$ The parameters of these two elements"fundamental rights" and "substantial reasons"-have been the subject of the Privileges and Immunities cases since Toomer. ${ }^{42}$

\section{B. Parsing the "Elements" of the Court's Current Test}

\section{The "Substantial Reasons"/"Close Relation" Element}

Courts have used the "substantial reason" and "close relation" element both to expand and to contract Privileges and Immunities rights. Accordingly, the new element has been a source of considerable uncertainty for cities. In Hicklin v. Orbeck, ${ }^{43}$ the first case in which the Court reviewed a public works local preference law, the State of Alaska had required that all contractors involved in oil- and gas-related work where the State was a party give preference to state residents. The Court determined that this blanket preference for state residents did not bear a close relation to combating the peculiar evil of nonresidents taking local jobs, as the State had not shown that the nonresidents actually caused local unemployment. Instead, the Court reasoned that the influx of out-of-state workers was likely only a symptom of the lack of education and skills and geographical remoteness of the local population. ${ }^{44}$ Moreover, the Court in Hicklin expressed in dicta that it was a doubtful proposition whether a State could ever discriminate against nonresidents to solve an unemployment problem, whatever the "substantial reason." 45

Hicklin may seem like the last word on resident preferences, but it was only the beginning. Several courts subsequently have taken a less strict approach, and have given defendant cities the chance to detail the particular economic circumstances that give them a "substantial reason" for nonresident discrimination. Indeed, this "substantial reason" test, even though it is difficult for a city to meet, can work in favor of local hiring plans. In United Building \& Construction Trades v. Camden, ${ }^{46}$ the Court reviewed a city resident hiring preference imposed on public works contractors and found a violation of the plaintiffs' fundamental right to pursue a common calling. Nevertheless, the Court remanded the

41. Non-residents faced a license fee that was 100 times greater than the fee for state residents, and all boats that fished in South Carolina waters were required to unload, pack, and stamp their catches at South Carolina docks. See id. at 389-91.

42. It is important to note that even though Toomer initiates the balancing of state interests against the infringement of fundamental rights, it does not necessarily mandate greater deference to state legislative decisions. Indeed, the Toomer Court struggled to distinguish that case from $M c C r e a d y$, in which the Court had found no Privileges and Immunities violation on similar facts. See id. at 400-02.
43. 437 U.S. 518 (1978).
44. See id. at 526-27 \& n.10.
45. Id. at 526 .
46. 465 U.S. 208 (1984). 
case for further findings as to what motivations, if any, lay behind the Camden ordinance. ${ }^{47}$ Thus, Camden has been useful to both plaintiffs and defendants in lawsuits involving local preference ordinances. On one level, it enshrines the notion that private employment on public works contracts is a fundamental right protected by the Privileges and Immunities Clause; on another level, it leaves open the possibility that a city can defend a local preference plan, however difficult it may be to do so. The Camden Court, therefore, did not share the Hicklin Court's belief that a State couId almost never justify local preferences.

Decisions of some lower courts further illustrate the flexibility that the refined, post-Toomer Privileges and Immunities test allows. Some lower courts have chosen to apply the "substantial reason/close relation" element of the test in a restrictive manner. The Seventh Circuit, for example, in W.C.M. Window Co. v. Bernardi, ${ }^{48}$ required a showing of costs and benefits to satisfy the "substantial reason" test. The court did not find it intuitively obvious that preventing nonresidents from working on public construction projects would benefit the State, and so required Illinois to show some sort of financial or employment data to justify its resident hiring preferences. ${ }^{49}$ Other courts have chosen to be more lenient. State v. Antonich, ${ }^{50}$ another case that involved resident preferences on state public works jobs, shows the possibility of meeting the "substantial reason" and "close relation" tests simply by defining the State's reason very narrowly. In Antonich, Wyoming simply identified the motivation underlying its local preference statute as the problem inherent im hiring a nonresident on a government-funded construction project while an available Wyoming resident remained unemployed. ${ }^{51}$ The statute required contractors to contact a local employment office to determine whether qualified resident workers were available and, if so, to hire them first. ${ }^{52}$ Defined as such, the statute easily bore a close relation to the State's goal, since anyone listed on the employment office's list would be unemployed or in some way looking for work.

Recent changes $m$ the doctrine have made it even less clear whether the "substantial reason" element of the test prescribes more narrow or more expansive Privileges and Immunities rights. Supreme Court of New Hampshire v. Piper, ${ }^{53}$ a case that involved a state residency requirement for the admission of lawyers to the state bar, is

\footnotetext{
47. See id. at 221-23.

48. 730 F.2d 486 (7th Cir. 1984).

49. See id. at $497-98$.

50. 694 P.2d 60 (Wyo. 1985).

51. See id. at 63.

52. See id.

53. 470 U.S. 274 (1985).
} 
primarily responsible for this uncertainty. In formulating its statement of the Privileges and Immunities test, the Piper Court failed to mention the "peculiar source of the evil" element that had caused Alaska so much trouble in Hicklin. Instead, the Court held that to pass Privileges and Immunities scrutiny, a State must show only that it has a substantial reason for discriminating against nonresidents, and that its method of discrimmation bears a substantial relationship to that objective. ${ }^{54}$ Indeed, the district court in International Organization of Masters, Mates \& Pilots v. Andrews ss noted this omission, writing that "the Piper decision [reformulated], albeit slightly, the analysis to be applied in privileges and immunities cases." 56 Such a change would considerably lower the Privileges and Immunities hurdle, as the "peculiar evil" part of the test has been particularly difficult for cities to overcome. ${ }^{57}$

However, Piper appears to have added an additional, different hurdle for local preference plans: a "less restrictive means" test. Under this new permutation, the Court will judge the "close relation" of a preference statute to the city's substantial reason in light of the other policy options which the city had available. To pass constitutional muster, the resident preferences must be "less restrictive" of the rights of nonresidents than these other policy options. ${ }^{58}$ Justice Rehnquist, dissenting in Piper, found this increased level of judicial scrutiny to be an unwarranted intrusion into State decision-making, and argued that the Court should defer to States and cities under the Privileges and Immunities Clause when they have a rational basis for their statutes. ${ }^{59}$ He noted further, with respect to the less restrictive means rationale, that "such an analysis, when carried too far, will ultimately lead to striking down almost any statute on the ground that the Court could think of another 'less restrictive' way to write it." ${ }^{\text {"60 }}$ Indeed, the less

54. See id. at 284.

55. 626 F. Supp. 1271 (D. Alaska 1986), vacated in part on other grounds, 831 F.2d 843 (9th Cir. 1987).

56. Id. at $1282 \mathrm{n} .12$; see also Werner Z. Hirsch, The Constitutionality of State Preference (Residency) Laws Under the Privileges and Immunity Clause, 22 Sw. U. L. Rev. 1, 18 (1992).

57. See, e.g., United Bldg. \& Constr. Trades Council v. Mayor of Camden, 443 A.2d 148, 151 (1982) (noting that mere coniparative statistics, e.g., comparisons between the unemployment rate within a city and the rate in the region as a whole, will not suffice to satisfy the Privileges and Immunities Clause); see also Hicklin v. Orbeck, 437 U.S. 518, 526-27 (holding that there was no evidence on the record that state nonresidents were the peculiar source of Alaska's high uneinployment, but rather that geographical remoteness and a lack of job skils were apparentiy to blame).

58. See Supreme Court of New Hampshire v. Piper, 470 U.S. 274, 284 \& n.17 (1985); see also Day, supra note 16, at 294-96 (noting the addition of this less restrictive means test).

59. See Piper, 470 U.S. at 295 (Rehnquist, J., dissenting) (arguing that Privileges and Immunities challenges "should be overcoine if merely a legitimate reason exists for not pursuing" a proffered less discriminatory path).

60. Id. at 294-95. 
discriminatory means analysis in Piper may have introduced something akin to a "strict scrutiny" analysis into the Privileges and Immunities Clause. This heightened level of scrutiny is particularly troublesome for local preference plans, given that a city could often conduct job training and job referral practices instead of inandating the preferences. ${ }^{61}$ What is more, courts have also continued to apply the "peculiar source of evil" element of the "substantial reason" test after Piper. ${ }^{62}$ Thus, Piper appears to have had an unequivocally negative impact on cities' flexibility, as it added a third element to an already difficult test. The next section discusses the remaining "fundainental rights" element.

\section{The "Fundamental Rights" Element}

To add to the confusion of current Privileges and Immunities analysis, it appears that the fundamental rights component of the inquiry-which logically precedes the "substantial reason" test-never lost its central importance, despite the changes worked by Toomer. However, what has changed since the 19th Century is that the Court today generally views the Clause as protective of individual rights, rather than of the general flow of trade and commerce. ${ }^{63}$ The fundamental rights question alone was dispositive in Baldwin v. Fish \& Game Commission of Montana, ${ }^{64}$ in which the Court upheld a state law that gave preferences to state residents in the allocation of elk hunting licenses. The Court simply held that elk hunting was not a fundamental right, and so, as in McCready v. Virginia, ${ }^{65}$ which was decided one hundred years earlier, the Court found no reason to take the inquiry further.

Since Toomer, courts have focused on the pursuit of a "common calling" as a fundamental right subject to Privileges and Immunities protection. Even within the category of "common calling," however, a city cannot be confident about what exactly constitutes a fundamental right. The federal district court in International Organization of Masters, Mates \& Pilots $^{66}$ upheld the constitutionality of a wage differential between state resident and nonresident employees, finding that receiving an equal wage did not amount to a fundamental right protected by the Privileges and Immunities Clause. In Supreme Court of Virginia

61. It is also possible that if the Court subjects local preference statutes to something greater than deferential review, a city may find little advantage in resident preferences over race-based affirmative action, which are already subject to a more exacting review. See supra notes 21-25 and accompanying text.

62. See, e.g., Hudson County Bldg. \& Constr. Trades Council v. City of Jersey City, 960 F. Supp. 1823 (N.D.N.J. 1996); 1st Westco Corp. v. Sch. Dist., 811 F. Supp. 204, 206 (E.D. Pa. 1993).

63. See Gergen, supra note 33 , at 1116 .

64. 436 U.S. 371 (1978).

65. 94 U.S. 391,396 (1876) (holding that out-of-state commercial fisherman lacked a fundamental right to access Virginia oyster beds).

66. 626 F. Supp. 1271, 1282-84 (D. Alaska 1986). 
v. Friedman ${ }^{67}$ however, the Supreme Court seemed to broaden the concept of "fundamental right" to encompass actual equality between residents and nonresidents. The Court held that Virginia could not permissibly deny nonresidents the privilege of admission to the State bar "on motion," or without taking the bar examination. ${ }^{68}$ Even though the inability of nonresidents to take advantage of Virginia's special discretionary admission procedure did not amount to a total bar on thcir pursuit of a common calling, the Court held that the Privileges and Immunities Clause guarantees citizens the right "of doing business in [a State] on terms of substantial equality with the citizens of that State."69 Thus, the right/privilege framework of the 19th Century cases and thc indeterminacy of the line between rights and privileges still befuddle modern courts.

These many Privileges and Immunities cases make clcar that Toomer's doctrinal boxes of "fundamental rights" and "substantial reason"/"close relation" are fuzzy at the boundaries. Indeed, it appears that most Privileges and Immunities cases hinge more on the reach or degree of the statute at issue than the exact judicial formula applied. Thus, the Wyoming Supreme Court in Antonich found that the state statute was not "wide-ranging" and that it "present[ed] minimal affront to thc privileges and immunities of noncitizens." "70 Similarly, the Court in Camden asserted rather firmly that private employment on public works contracts constitutes a fundamental right protected by the Privileges and Immunities Clause. ${ }^{71}$ The Court then retreated a bit to add that public control of the funds involved would be a crucial factor in determining whether the State had a substantial reason for discriminating against nonresidents. ${ }^{72}$ The Andrews district court blurred Camden's delicate distinction, finding that public ownership must be considered in determining whether the privilege at issue is truly fundamental. ${ }^{73}$ So it is unclear whether public spending correctly operates at the fundamental right level of analysis, at the substantial reason stage, or not at all.

Although it is true that circuit court opinions on the Privileges and Immunities Clause are rare relative to other constitutional provisions, ${ }^{74}$

67. 487 U.S. 59 (1988).

68. Id. at $65-66$.

69. Id. at 65 (quoting Supreme Court of New Hampshire v. Piper, 470 U.S. 274, 280 (1985)).

70. State v. Antonich, 694 P.2d 60, 64 (Wyo. 1985).

71. See United Bldg. \& Constr. Trades Council v. Mayor of Camden, 465 U.S. 208, 221-22 (1984).

72. See id. at 222 .

73. See Int'l Org. of Masters, Mates \& Pilots v. Andrews, 626 F. Supp. 1271, 1283-84 (D. Alaska 1986).

74. See Reynolds, supra note 20, at $806 \mathrm{n} .17$ (noting that "the Privileges and Immunities Clause has not been extensively litigated"). Reynolds also notes that "circuit court case law addressing hiring preferences ... is relatively sparse." $I d$. at 817. 
resident preferences is one of the more widely litigated issues under the Clause. ${ }^{75}$ And litigation could likely increase in the future due to the large number of recent state and city hiring preference laws. ${ }^{76}$ The existing litigation already has had a noticeable impact on the design of resident preference ordinances. Even a cursory look at the two statutes from Oakland and East Palo Alto quoted at the beginning of this Part ${ }^{77}$ reveals language that reflects the particular elements of the Privileges and Immunities test, including a clear statement of the economic motivations of the program and an attempt to link local economic distress to the influx of nonresidents.

But courts need not be so unkind, nor so unpredictable, when reviewing these ordinances. As described below, there is room in the doctrine to find local preference laws constitutional.

III

\section{The MARKet Participant EXCEPTION}

A close cousin to the Privileges and Immunities Clause, the Commerce Clause similarly appears to protect the nation's economic unity against state encroachment. ${ }^{78}$ While the Commerce Clause provides an affirmative grant of power to Congress over interstate commerce, it also implies the converse, that is, that States cannot regulate interstate commerce. The Court gives life to this "dormant" side of the Commerce Clause by striking down state laws of facial economic protectionisin, as well as laws that place an undue burden on interstate commerce. ${ }^{79}$ Pursuant to this doctrine, courts potentially could view a resident hiring preference as placing an undue burden on interstate commerce because the program impedes the ability of workers to seek employment across state lines. However, there exists a judicially created nnarket participant exception to the Dormant Commerce Clause which works in certain cases to exempt a city or State from the restrictions implied by Congress' plenary Commerce Clause powers. ${ }^{80}$ The market participant exception enables cities to enact hiring preferences and to take other actions when such behavior does not constitute "regulating commerce." Despite the state program's often protectionist motives

75. See id. at 806-07 n.17 (asserting that "litigation in recent years has refined the Privileges and Immunities Clause... particularly with respect to liring preferences").

76. See id. at 803 n.1, 817-19 (eiting recent liring preference laws).

77. See supra notes $26-27$.

78. See supra notes 8-10 and accompanying text.

79. See Dan T. Coenen, Untangling the Market-Participant Exemption to the Dormant Commerce Clause, 88 Mich. L. REv. 395, 398-400 (1989).

80. See, e.g., Hughes v. Alexandria Scrap, 426 U.S. 794, 808-10 (1976) (holding that when a State enters the market as a purchaser, the Dormant Commerce Clause does not prevent the State from restricting its trade to its own citizens and businesses). 
and effects, the market participant exception deems such "nonregulatory" action as nonthreatening to Congress' power to regulate commerce.

Currently, there is no exception under the Privileges and Immunities Clause which is analogous to the Dormant Commerce Clause's market participant exception. However, under the publicspending-based exception to the Privileges and Immunities Clause proposed herem, a city would enjoy market participant prerogatives by virtue of spending its own money. Public works contracting would fall within this definition of market participation because a city pays contractors and purchases labor with its own money, much as a private business that seeks to construct a building or commission services. Although the Court does not recognize this public spending exception to the Privileges and Immunities Clause, as argued below, such an interpretation is a reasonable extension of the current market participant and Privileges and Immunities doctrines.

This Part describes the market participant exception as it currently exists under the Dormant Commerce Clause. It then explains how the Court could recognize a similar public spending exception to the Privileges and Immunities Clause because jobs created by public spending do not implicate a "fundamental right" protected by the Clause. Accordingly, a city would invoke its market participant status at the first level of the Toomer test and claim that there is no "fundamental right" to jobs created from public spending. Next, this Part will analyze whether the proposed public spending exception can withstand the criticisms frequently levied against the market participant exception in the Dormant Commerce Clause context. Finally, this Part will analyze whether the public spending exception could apply even in cases in which cities spend state and federal money.

\section{A. The Status of the Market Participant Exception}

The Court developed the market participant exception within its Dormant Commerce Clause jurisprudence to define a range of state and local behavior not considered "regulation," which, therefore, did not offend Congress' power to regnlate commerce. The Court first recognized the exception in 1976 in Hughes v. Alexandria Scrap Corp., writing, "[n]othing in the purposes animating the Commerce Clause prohibits a State, in the absence of congressional action, froin participating in the market and exercising the right to favor its own citizens over others." ${ }^{\prime 11}$ With this reasoning, the Court allowed the state of Maryland to give a special "bounty" for the return of state-licensed

81. 426 U.S. 794, 810 (1976). 
junked automobiles. White v. Massachusetts Council of Construction Employers $^{82}$ applied this same theory to a city's local contracting preferences. In White, the plaintiffs charged that the city of Boston, by enacting a local hiring ordinance, had impeded interstate commerce and had intruded upon the exclusive commerce power of Congress. The Court, however, held that Boston's ordinance did not implicate the Commerce Clause because the city had simply placed restrictions on the use of its own funds or on funds it administered. Under the Court's reasoning, Boston's action was deemed market participation, rather than regulation, because Boston made an expenditure of its own funds. Thus, public spending was at the core of this market participant determination. ${ }^{83}$

The line between market participation and regulation is by no means clear. The year after White, the Court in South-Central Timber Development, Inc. v. Wunnicke held unconstitutional an Alaska statute that required harvesters of state-owned timber to process the timber in the State. ${ }^{84}$ Alaska argued that its restriction was merely a subsidy to local interests of the kind found inoffensive in Alexandria Scrap. However, the Court found that Alaska imposed a "downstream" condition on the market that went beyond mere market participation because it was attempting to control the behavior of private companies outside of their immediate dealings with the State. ${ }^{85}$ The Court reasoned that the market in which Alaska participated was the nnarket among timber companies to harvest state-owned timber, and that Alaska did not truly participate in the market for timber processing facilities. The moment when public resources left the government's hands thus served as the important dividing line in South-Central Timber between market participation and regulation.

But this holding seems to conflict with White, in that White held that even after a public resource-that is, money-entered private hands, the government could still control its use. Indeed, the market for construction labor could be seen as "downstream" from the market for construction contracts, in which Boston participated directly. The Court in White recognized that there are some limitations to the conditions that a city can impose on the parties with whom it does business,

82. 460 U.S. 204 (1983).

83. See id. at 210. With respect to the administration of federal funds, the Court in White found no Commerce Clause violation because Congress had authorized local hiring, at least implicitly, through provisions of the legislation that created the federal funds that the city of Boston was administering on the project. See id. at 213. In the eyes of the Court, this Congressional acquiescence eliminated the intergovernmental conflict otherwise at issue. However, the Court specifically declined to state what role, if any, federal authorization would play for the purposes of the Privileges and lmmunities Clause. See id. at 215 n.1 (Blackmun, J., dissenting).

84. See 467 U.S. 82, 97-98 (1984).

85. See id. at 95 . 
but declined to define those limits exactly. Instead, the Court held that the city's action fell "well within the scope" of the market participant exception. ${ }^{86}$

It should be noted that it is unclear how much of the market participant exception survived the Court's decision in Garcia v. San Antonio Metropolitan Transit Authority. ${ }^{87}$ Garcia held that the Court would no longer recognize any "traditional" areas of state authority or autonomy. ${ }^{88}$ The market participant/regulator distinction was one of the manifestations of this pre-Garcia effort to define the traditional areas of state sovereignty, an effort that the Garcia court criticized as not "faithful to the role of federalism in a democratic society." Accordingly, some commentators have read Garcia as putting an end to the market participant exception..$^{90}$ However, it is clear that the market participant exception is not dead, as the Court has confirmed the existence of market participant immunity in several cases since Garcia. ${ }^{91}$

86. White, 460 U.S. at 211 n.7.

87. 469 U.S. 528 (1985).

88. See id. at 546. The Court had espoused this traditional areas doctrine in National League of Cities $v$. Usery, 426 U.S. 833 (1976), and in the nine years following that decision tried to flesh out the parameters of these traditional areas. In Garcia, the Court determined that this effort to carve out a State's immunity from federal regulation based on the traditional areas of sovereignty was "unsound" and "unworkable," and that it "inevitably invites an unelected federal judieiary to make distinctions about which state policies it favors and which ones it dislikes." Garcia, 469 U.S. at 546. By revoking the doctrine, the Court thereby placed a limit on the ability of a city or state to insulate itself from federal regulation.

89. Garcia, 469 U.S. at 546.

90. See Swin Resource Systems, Inc. v. Lycouning County, 883 F.2d 245, 257 (3rd Cir. 1989) (Gibbons, C.J., dissenting) (arguing that Garcia did away with the market participant exception); Karl Manheim, New-Age Federalism and the Market Participant Doctrine, 22 ARIz. ST. LJ. 559, 602-10 (1990). But the Court made clear that its primary focus was the uselessncss of the "integral" or "traditional" concepts. See Garcia, 469 U.S. at 546. Indeed, the Court's motivation appears to have been a concern for state flexibility in ineeting the changing needs of society. The Court notcd that "States must be equally free to engage in any activity that their citizens choose for the common weal, no matter how unorthodox or unnecessary anyone else-including the judiciary-deems state involvement to be." Id. Although the Court eertainly maligned the government/proprietor distinction, this quoted passage actually inplies an expansion of States' ability to enter markets and conduct other "nentraditional' pregrams free of ill-fitting labe!s. See Coenen, supra note 79, at $407 \mathrm{n} .86,429-30$ (1989) (argning that Garcia operates to expand market participant immunity). See also Big Country Foods, Inc. v. Bd. of Educ., 952 F.2d 1173, 1180 (1992) (in which the court rejected the plaintiff's argument that because the school district was acting in a sovereign capacity, it could not claim the market participant exception).

91. See, e.g., Bldg. \& Constr. Trades Council v. Ass'n Builders \& Contractors, 507 U.S. 218 (1993) (holding that the National Labor Relations Act does not preempt contract bid specifications by a state agency when that agency cperates as a market participant and where the specification would be lawful for a private actor); Wyoming v. Oklahoma, 502 U.S. 437 (1992) (holding that a state agency acted as a market participant in its purchases of coal, but finding a Commcrce Clausc violation nonetheless); New Energy Co. v. Limbaeh, 486 U.S. 269, 277 (1988) (affirming the existence of the market participant exception, but not applying it to that case); Wisconsin Dept. of Indus., Laber \& Human Relations v. Gould Inc., 475 U.S. 282, 289 (1986) (holding that prohibitions on gevernment agency's purchases from labor law violators was not market participation); see also Cory v. Western Oil \& Gas Ass'n, 471 U.S. 81 (1985) (affirming a circuit court decision that had 
The exception's continuing validity notwithstanding, no analogous exception currently exists under the Privileges and Immunities Clause. Although the local preference plan in White could reasonably have been expected to implicate the Privileges and Immunities Clause, the Court specifically declined to address whether an analogous exception would exist under the Clause. ${ }^{92}$ Camden seems to clearly answer this question in the negative. The Camden Court, analyzing a local hiring plan under the Privileges and Immunities Clause, wrote that "the distinction between market participant and inarket regulator relied upon in White to dispose of the Commerce Clause challenge is not dispositive in this context. ${ }^{.93}$ The Court reasoned that the market participant exception acts to alleviate the conflict between state power and federal power, a conflict that the Commerce Clause directly addresses. When a State acts as a market participant, it is not truly exercising its government power, but only acting like any other employer, and so does not threaten the plenary commerce power of Congress. ${ }^{94}$ Because the Privileges and Immunities Clause does not address this conflict between state and federal power, but rather addresses the conflict between States, or between States and individuals, the Camden Court found the market participant exception inappropriate..$^{95}$ Thus, according to Camden, cities spending their own money and operating local preference plans are not exempt from the strictures of the Privileges and Immunities Clause.

The purported rationale that Camden offers for the distinction between market participation analysis under the Dormant Commerce Clause and the Privileges and Immunities Clause is insufficient. The Court's inere mention of the differences between the two Clauses fails to explain why the market participant exception would be inappropriate in the context of state power and individual rights. Unless one views the individual rights under the Privileges and Immunities Clause as more worthy of protection than the powers of Congress under the Commerce Clause, the market participant rationale would seem to apply to both situations equally. In the same way that the Court finds that private, proprietary actors do not impede the ability of Congress to exercise its authority under the Commerce Clause, so too could the Court find that proprietary actors do not implicate the right to a common calling that is protected under the Privileges and Immunities Clause.

The market participant exception works because courts deem that the Commerce Clause is concerned primarily with instances of state

reaffirmed the existence of the market participant exception, but had determined that the State's monopoly power prevented it from invoking the exception).

92. See id. at 214 n.12.

93. United Bldg. \& Constr. Trades Council v. Mayor of Camden, 465 U.S. 208, 219-20 (1984).

94. See id. at 220.

95. See id. at 221 . 
regulation. Because courts view proprietary state actions as something other than regulation, they can view these proprietary actions as resting outside the purview of the Commerce Clause. In a similar fashion, a public spending exception could work under the Privilcges and Immunities Clause if courts begin with the rccognition that the Clause protects individual rights that are fundamental to national unity. ${ }^{96}$ If proprietary government action does not threaten a fundamental individual right, then courts could judge that such action does not fall within the purposes of the Privileges and Immunities Clause. Courts would then exempt such proprietary government action from curtailment under the Privileges and Immunities Clause, just as they currently do under the Commerce Clause.

It is important to note, however, that this analogy to the market participant exception only works if courts can say definitively that proprietary government action does not implicate a fundamental right under the Privileges and Immunities Clause. Accordingly, the following Section attempts to answer this critical question of whether there exists a fundamental Privileges and Immunities right to a private job on a publicly funded project.

Although this extension of the market participant rationale is reasonable, the Camden Court was nevertheless correct to notice that the market participant doctrine's focus on the character of state power seems inapplicable in the Privileges and Immunities context. Indeed, the Privileges and Immunities Clause, unlike the Commerce Clause, is not concerned with the character of government action so much as the individual right infringed. The Privileges and Immunities doctrinc asks first whether a fundamental individual right has been violated, and then looks for a city's substantial reason for this violation. If a public spending exception were to apply to the Privileges and Immunities Clause, it would apply because individuals do not have a fundamental right to a city's proprietary expenditures, not because the city is able to draw a firm distinction between its public spending, as a market participant, and its regulation. Thus, an analogous exception to the Privileges and Immunities Clause is more properly called a "public spending exception," as it would distill this more important element of market participation. The discussion below explains why such a public-spending-based application of the market participant exception is reasonablc.

96. See supra notes $30-37$ and accompanying text. 


\section{B. Is There a Fundamental Right to a Private Job on a Publicly Funded Project?}

In order to be excepted from the strictures of the Privileges and Immunities Clause, a state or local statute must not violate a fundamental right protected by the Clause. Under general principles of constitutional inquiry, States can exercise whatever powers they wish absent federal constitutional restrictions. ${ }^{97}$ The protection of the Privileges and Immunities Clause is one such limit on state power, defining areas of national concern where States cannot regulate. Thus, the realm of "fundamental rights" defines the limit of state power with respect to the Privileges and Immunities Clause. But despite the importance of this distinction between fundamental and nonfundamental rights, courts have not ruled consistently on the parameters of the distinction. Clearly, the ability to pursue a common calling is such a right, ${ }^{98}$ while equal access to elk hunting licenses is not. ${ }^{99}$ The ability to get a job on a publicly funded construction project, like most rights and privileges, falls somewhere in between these extremes. But based on the use of public funds on these projects, courts could find that individuals do not have a right to the proprietary funds of a political community to which they do not belong. ${ }^{100}$

To explain why such a categorical determination makes sense, this Section will first demonstrate that direct hiring by the government without the "middleman" of a private contractor does not implicate a fundamental right under the Privileges and Immunities Clause. Then, the Section will extend the argument developed for direct hiring to the wider-ranging case of indirect hiring, or private jobs on publicly funded projects.

\section{Direct Government Employment}

There are many disbursements of government largesse which do not implicate fundamental rights under the Privileges and Immunities Clause. States and cities can limit access to public schools, welfare payments, and university tuition reductions to local residents. ${ }^{101}$ These

97. See U.S. CoNST. amend. X; Garcia, 469 U.S. at 549 (holding that States retain sovereign authority "only to the extent that the Constitution has not divested them of their original powers and transferred these powers to the Federal Government").

98. See Camden, 465 U.S. at 219.

99. See Baldwin v. Fish \& Game Comm'n, 436 U.S. 371 (1978).

100. When cities spend federal funds-inoney that is not their own-the analysis is somewhat different. See infra Section II.D.

101. See, e.g., Martinez v. Bynum, 461 U.S. 321 (1983) (upholding a state residence requirement for free public schools); Shapiro v. Thompson, 394 U.S. 618 (1969) (holding only that durational residence requirements for welfare eligibility violate the Fourteenth Amendment); Sturgis v. Washington, 368 F. Supp. 38 (W.D. Wash. 1973), aff'd 414 U.S. 1057 (1973) (holding that durational residence requirements for reduced tuition do not present a Fourteenth Amendment violation). These 
benefits do not give rise to a fundamental right under the Privileges and Immunities Clause because their existence depends both on state and local taxes levied from local residents and on public will to spend tax revenue in particular ways. ${ }^{102}$ The idea is that each member of the community has a right to those funds that she has helped create by participating in the economy and paying taxes; conversely, no member of the community has a right to the funds created by another community ${ }^{103}$ Thus, each community can choose to disburse its funds within the community without implicating the rights of citizens from other communities. With these different exercises of government spending power, a city or State defines itself as a separate and distinct political community. ${ }^{104}$

The Court has also held that there is no right to a government job. In McCarthy v. Philadelphia Civil Service Commission, ${ }^{105}$ the Court upheld a municipal ordinance that required all Philadelphia city government employees to be residents of the city. The plaintiff brought a claim based on the right to travel, but the Court noted more broadly that there is no support for the clain that one has a constitutional right to be employed by a city while living elsewhere. ${ }^{106}$ The Court also held in White v. Massachusetts Council of Construction Employers ${ }^{107}$ that the Commerce Clause does not provide a right to a government job.

Admittedly, however, the Court has not addressed whether the Privileges and Immunities Clause specifically creates a right to direct government employment. ${ }^{108}$ In Camden, the Court acknowledged the distinction between public and private employment in discussing the

cases uphold residence requirements against challenges brought under the Equal Protection Clause, not the Privileges and Immunities Clause. Nevertheless, there is no evidence of successful Privileges and Immunities challenges to these types of preferences. See Jonathan D. Varat, State "Citizenship" and Interstate Equality, 48 U. CHI. L REv. 487, 553 (1981) ("Little question has been raised about state power to reserve elementary and secondary public schools for resident use.").

102. Of course, many such benefits are funded with federal dollars, a fact that changes the analysis somewhat. See infra Section II.D.

103. Variations on this theme of state-created resources receive wide support in the literature. See, e.g., Laurence H. Tribe, Constitutional Choices 146 (1985) (explaining that a State has greater freedom to intrude into the market when it has created commerce that would not otherwise exist); Coenen, supra note 79, at 421-26 (positing a "reaping and sowing" rationale, whercby state residents can fairly gain preferential access to resources they create); Gergen, supra note 33, at 1100 (arguing that States may favor their own citizens in the allocation of state-provided goods "for which some redistributional or other interest justifies allocation by communal affiliation rather than through market transactions"); Varat, supra note 101, at 523 (arguing that state residents may channel resources to themselves if they themselves have created the State's benefits).

104. See Supreme Court of New Hampshire v. Piper, 470 U.S. 274, 282 n.13 (1985).

105. 424 U.S. 645 (1976).

106. See id. at 646-47; see also Massachusetts Bd. of Retirement v. Murgia, 427 U.S. 307,313 (1976) (per curiam) (decided on equal protection grounds).

107. 460 U.S. 204 (1983).

108. See Salem Blue Collar Workers Ass'n v. Salem, 33 F.3d 265, 268 (3d Cir. 1994). 
right to pursue a common calling under the Privileges and Immunities Clause. The Court stated that "[p]ublic employment ... is qualitatively different from employment in the private sector; it is a subspecies of the broader opportunity to pursue a common calling." 109 The Court, however, did not describe the "public employment" to which it referred: direct employment, indirect employment, as in public contracting, or both. The Court also did not explicitly extend to its Privileges and Immunities analysis the holdings on direct employment that it had reached under the Equal Protection and Commerce Clauses. Moreover, the facts before the Court imvolved only indirect public employment. ${ }^{110}$ At best, it is unclear just what the Camden Court held with respect to direct public employment; that is, whether it rejected the public/private distinction for any type of employment as irrelevant to a Privileges and Immunities analysis, or merely rejected the distinction in the particular case of contracting and indirect hiring. ${ }^{111}$

An analysis of the purposes of the Privileges and Immunities Clause-protection of economic unity in general, and the individual rights, in particular, to pursue a common calling-indicates that direct government hiring does not implicate the Clause's concerns. The Supreme Court has noted that the Privileges and Immunities Clause, like the Commerce Clause, was designed to prevent state protectionism and econounic balkanization. ${ }^{112}$ But under the Court's Dormant Commerce Clause jurisprudence, it has determined that direct hiring and other types of market participation do not implicate the concerns of economic unity behind the Clause. ${ }^{113}$ If the purposes of the Commerce Clause and the Privileges and Immunities Clause are the same, then it makes little sense to conclude that preferences in direct hiring would somehow implicate national economic unity when viewed under one clause but not the other.

Another perspective on the Privileges and Immunities Clause, as argned in this Comment, is that the Clause protects individual rights. Under this perspective, the Privileges and Immunities Clause-in its desire to ensure equal treatment of all U.S. citizens by the various States-can be seen as similar to the Equal Protection Clause of the Fourteenth Amendment. ${ }^{114}$ The two clauses are also similar in that they

109. United Bldg. \& Constr. Trades Council v. Mayor of Camden, 465 U.S. 208, 219 (1984).

110. See id.

111. See id. at 219-20.

112. See infra notes $133-134$ and accompanying text.

113. See, e.g., White v. Massachusetts Council. of Constr. Employers, Inc., 460 U.S. 204, 211 n.7 (1983).

114. For example, the right to travel has been understood both as a Privileges and Immunities right and as an Equal Protection right. See Attorney Gen. v. Soto-Lopez, 476 U.S. 898, 902-04 (1986) (holding that restrictions on the right to travel implicate both the Privileges and Immunities Clause and the Equal Protection Clause); see also Int'l Org. of Masters, Mates \& Pilots v. Andrews, 626 F. Supp. 
both declare a set of "fundamental" rights that are protected. The scope of fundamental rights under the two clauses is similar, though not identical. ${ }^{115}$ Since the Equal Proteetion Clause does not provide a right to a government job for nonresidents, ${ }^{116}$ then unless one believes that the scope of fundamental rights under the Privileges and Immunities Clause should be significantly broader than under the Equal Protection Clause, preferences in direct government hiring should implicate neither clause. Thus, whether viewed as protective of economic unity or individual rights, the Privileges and Immunities Clause does not provide a fundamental right to a government job.

Furthermore, direct hiring is comparable to the other exercises of government largesse described above in that it contributes to the formation of separate and distinct political communities. Direct hiring, like the provision of education or welfare benefits, represents a colleetive decision among members of a political community about their economic and political priorities. Like other ways in which city and state governments spend money, direct hiring represents a community's decision about how to disburse the resources that it owns and controls. Under this rationale, several lower courts and commentators have asserted that such direct employment is not protected by the Privileges and Immunities Clause. ${ }^{117}$ The Third Circuit in Salem Blue Collar Workers Association v. Salem, for example, came to this conclusion based on an historical reading of the Privileges and Immunities Clause, finding that it was intended to apply to private commerce only. ${ }^{118} \mathrm{Di}$ rect hiring, therefore, does not implicate a fundamental right under the Privileges and Immunities Clause.

\section{Indirect Government Employment: Public Works Contracts}

Even if Camden glosses over this question of direet hiring, it clearly does not grant such a market participant exception for public works contracting or indirect hiring, but rather considers such jobs to be

1271,1278 (D. Alaska 1986) (wherein the plaintiff argues that the wage differentials at issue violate the right to travel guaranteed by the 14th Amendment (citing Memorial Hosp. v. Maricopa County, 415 U.S. 250 (1974); Dunn v. Blumstein, 405 U.S. 330 (1972); Shapiro v. Thompson, 394 U.S. 618 (1969))). But see Edwards v. California, 314 U.S. 160, 164 (1941) (noting that "Article IV, § 2 ... was intended to insure to each of the citizens of the several States the fundamental right to move about freely ... in search of opportunity").

115. See Aldering v. Ohio High Sch. Athletic Ass'n, 779 F.2d 315, 318 (6th Cir. 1985) (holding that "fundamental" under the Privileges and Immunities Clause may encompass some rights not guaranteed by the Fourteenth Amendment).

116. See supra note 106 and accompanying text.

117. See, e.g. Charles H. Clarke, Local Hire and the State-Market-Participant Doctrine: A Trojan Horse for the Commerce Power of Congress, 33 Clev. ST. L. REv. 191, 208-09 (1984-85); Day, supra note 16 , at 277.

118. See 33 F.3d 265, 268-70 (3d Cir. 1994). 
private employment. ${ }^{119}$ This interpretation conflicts directly with the analysis in White. In White, the Court held that if the Dorınant Commerce Clause does not provide a right to work directly for a city, then it also does not provide a right to work for a contractor who works for the city. White determined that contractors, subcontractors, and their einployees should all be considered "working for the city." 120 The Camden Court, however, after noting the importance of "working for the city" in Equal Protection and Dormant Commerce Clause analysis, held that it would not "transfer inechanically into this context an analysis fashioned to fit the Commerce Clause." ${ }^{.21}$ Indeed, the Court found that determining whether these contracting employees are considered "working for the city" would be irrelevant to whether the city violated plaintiff's fundamental Privileges and Immunities. ${ }^{122}$

But given the relevance of public spending and public ownership to the question of fundamental rights, the Court dismissed the "working for the city" rationale too easily. Indeed, in the context of direct hiring, as described above, the questions for whom one works and a job's source of funds are central to a Privileges and Immunities inquiry. These factors place direct employment outside the realm of fundamental rights; accordingly, the presence of a private contractor (essentially a "middleman" between the city and workers, or even a conduit for the city's funds) should make little difference to the analysis.

Under Privileges and Immunities scrutiny, public works contracting jobs will either be deemed a fundamental right-a right that impacts the vitality of the nation as a whole ${ }^{123}$-or simply an elennent of defining a city as a separate and distinct political community, and so nonfundamental. Public works contracting jobs should fall outside the realın of fundanental rights because the dependence of these jobs on public money means that they are only marginally different in character from the other disbursements of government largesse described above, such as

119. See id. at 270 (describing Camden).

120. White v. Massachusetts Council of Constr. Employers, Inc., 460 U.S. 204, 211 n.7 (1983) (decided on Commerce Clause grounds). White and Camden differ only in the constitutional test applied; their facts are remarkably similar. In fact, the White Court deliberately declined to address the Privileges and Immunities question, asserting that the Privileges and Immunities issue had not been briefed by either party. See id. at 214 n.12. However, note also that Camden's interpretation of public contracting as private employment comports with earlier state court decisions on the Privileges and Immunities Clause. See, e.g., Laborers Local Union No. 374 v. Felton Constr. Co., 654 P.2d 67, 70 (1982) ("The capacity to pursue work is fundamental whether in a public or private context.").

121. Camden, 465 U.S. at 219; see also Neshaminy Constructors, Inc. v. Krause, 437 A.2d 733, 738 n.6 (1981) (holding that public employment cases are mappositc to situations involving private enployers on public works projects) (citing Sugarman v. Dougall, 413 U.S. 634 (1973)).

122. See Camden, 465 U.S. at 221 ("A determination of whether a privilege is 'fundamental' for purposes of that Clause does not depend on whether the employees of private contractors and subcontractors engaged in public works projects can or cannot be said to be 'working for the city'.").

123. See Day, supra note 16 , at 276 \& nn. 30-31. 
public education, welfare benefits, and direct public employment. ${ }^{124}$ Residents "own" these public funds due to their tax contributions, so they should be able to decide collectively how to spend them. ${ }^{125}$ Residents have a right to these funds; nonresidents do not. Indeed, if the Privileges and Immunities Clause protects the right to pursue a "common calling," then the presence of public funds makes both direct government employment and contracting jobs less than "common." Thus, there appears to be no principled distinction between public contracting and direct hiring under a fundamental rights analysis: neither necessarily implicates the Privileges and Immunities Clause.

This argument for a categorical exclusion of public works contracting from Privileges and Immunities scrutiny alters only slightly the approach taken by some courts in reviewing local preference plans. The Camden Court held that the principal characteristic of market participation-that a city is spending its own money-is a significant factor arguing against a Privileges and Immunities violation. ${ }^{126}$ The Court allowed this public spending factor to enter the analysis at the second stage of the Toomer test, in determining whether a substantial reason exists for discrimination against nonresidents. The Wyoming Supreme Court followed this methodology in State $v$. Antonich, and held that because Wyoming's local preference law had limited its discriminatory effect to government-created jobs, it presented a "minimal affront to the privileges and immunities of noncitizens." 127 Antonich's holding is significant because Wyoming had offered a considerably weaker showing of its "substantial reason" than was demanded of either Alaska in Hicklin or Illinois in Bernardi. ${ }^{128}$ Thus, the presence of public spending operated as almost a per se exclusion of Wyoming's program from Privileges and Immunities review.

Local hiring requirements, in fact, may be among the easier exercises of market participatory power for a court to analyze, given the range of economic development programs in which cities engage. In addition to requirmg local labor on public works contracts, a city might offer tax breaks or other monetary incentives to businesses that locate in that city. The city might also provide non-monetary incentives, such as building a highway that provides a specific benefit to a particular

124. See supra note 101 and accompanying text.

125. While the classification of "resident" does not have a perfect correlation to the group of individuals who contributed tax dollars to make those public works jobs possible, it is a close proxy, and apparently close enough for the other areas of government spending such as education provision and direct hiring.

126. See Camden, 465 U.S. at 222.

127. State v. Antonich, 694 P.2d 60, 64 (Wyo. 1985).

128. Compare id. with Hicklin v. Orbeck, 437 U.S. 518, 526-27 \& n.10 (1978), and W.C.M. Window Co. v. Bernardi, 730 F.2d 486, 497-98 (7th Cir. 1984). 
business. The city could also enter into participation agreements with local businesses to conform their signage to the standards of a community development district, or pursue myriad other strategies. These examples show progressively less resemblance to the traditional "buying and selling" model of market participation, and may implicate Privileges and Immunities rights in a way that buying and selling do not. And as cities place local hiring requirements on these types of nonmonetary benefits and contracts, the operative question under a Privileges and Immunities analysis becomes whether there is an individual right to these government gratuities. With a public-spendingoriented market participant exception, the answer depends on the extent to which these benefits rely on public expenditure.

\section{Defending against Criticisms of the Market Participant Exception}

The preceding Section describes how courts could, and ultimately should, employ the market participant rationale and create a special status for jobs created through public spending; however, the market participant exception as it currently exists under the Commerce Clause is not without its critics. In fact, critics have attacked the market participant exception as unrealistic and unworkable, ${ }^{129}$ and presumably, a public spending exception would be subject to these same criticisms. Most notably, critics argue that such state action contributes to economic balkanization, ${ }^{130}$ that it is impossible to distinguish sovereign from proprietary state activities, ${ }^{131}$ and that government entities simply never act out of pure economic motives, as would true private market participants. ${ }^{132}$ But a public spending exception, which exempts jobs created from public funds, is different from traditional market participation which exempts government action that can be deemed proprietary and not regulatory. Moreover, as this Section will illustrate, a publicspending-based market participant exception under the Privileges and Immunities Clause does not implicate any of these concerns of a traditional market participant exception.

\section{Economic Balkanization}

A popular criticism of the market participant exception is that it allows city and state protectionism, and that both the Privileges and Immunities and the Commerce Clauses were designed to avoid the

129. See e.g., Clarke, supra note 117, at 211; Manheim, supra note 90, at 582-610.

130. See e.g., Clarke, supra note 117, at 199; Day, supra note 16, at 300-01; Manheim, supra note 90 , at 619 .

131. See e.g., South-Central Timber Dev., Inc. v. Wunnicke, 467 U.S. 82, 102 (1984) (Rehnquist, J., dissenting); Clarke, supra note 117, at 211-14; Manheim, supra note 90, at 607-08.

132. See, e.g., Manheim, supra note 90 , at $604-05,608$. 
economic balkanization that results from such protectionism. ${ }^{133}$ It is true that a concern for interstate comity and economic unity motivated both clauses, and that they both have roots in Article IV of the Articles of Confederation. ${ }^{134}$ Nevertheless, the very existence of a federal structure indicates that the Constitution did not eradicate the ability of states to pursue different economic policies, with different levels of taxation and different spending priorities. ${ }^{135}$ Indeed, "economic unity" does not mean "free trade," and the anti-protectionist sentiments in the Constitution do not support such a policy preference.

Some courts and commentators assert that there exists a national policy of economic unity. ${ }^{136}$ Yet to the extent that there is a textual or historical basis for such a policy, it surely must be limited by concerns of federalism. And such a policy surely does not prohibit any state economic activity that benefits local residents. Indeed, the Supreme Court has noted that state taxation and regulation were the motivating factors behind the Commerce Clause, ${ }^{137}$ and at least one commentator has asserted that the Framers intended to outlaw state discrimination on the basis of residence only in the regulation of access to the private sector. ${ }^{138}$ But the effort of mining the historical record to determine original intent is beyond the scope of this Comment; moreover, such an effort is unecessary. Given that any national policy of economic unity must be limited by concerns of federalism, a court can be faithful to these two competing concerns only by testing each economic action of a State or city for its impact on interstate commerce.

It also should be noted that the requirements and parameters of "national economic unity" under the Privileges and Immunities Clause have fluctuatcd greatly over time. Compare, for example, McCready $v$. Virginia $^{139}$ (I876), which held that nonresident commercial fishermen did not have a fundamental Privileges and Immunities right to fish at

133. See e.g., Clarke, supra note 117, at 199; Day, supra note 16, at 300-01; Manheim, sıpra note 90 , at 619.

134. See Hicklin v. Orbeck, 437 U.S. 518, $531-32$ \& n.16 (1978); see also Baldwin v. Fish \& Game Comm'n, 436 U.S. 371, 379-80 (1978) (noting that the two clauses have a "mutually reinforcing relationship").

135. See Varat, supra note 101, at $\mathbf{5 2 2}$ ("The states' wide range of independent lawmaking authority necessarily prevents complete realization of a national free trade unit. When the Framers provided for concurrent federal and state taxing, spending, and regulatory powcrs, they sanctioned a diversity of policies among the states.").

136. See, e.g., Salla v. County of Monroe, 399 N.E.2d 909, 915 (N.Y. 1979); Day, supra note 16, at 274 (asserting that the Privileges and Immunities and Commerce Clauses have the common purpose of protecting against state laws that "inhibit the growth of a competitive national market and a unified people").

137. See Hughes v. Alexandria Scrap Corp., 426 U.S. 794, 807-08 \& n.16 (1976); LAURENCE H Tribe, American Constitutional Law 404 (1978).

138. See Varat, supra note 101, at 522.

139. 94 U.S. 391 (1876). 
another State's oyster beds, with Toomer $v$. Witsell ${ }^{140}$ (1948), which held that nonresident shrimp fishermen did have a fundamental right to fish in another State's shrimping waters. Further evidence of the changing character of the economic protections afforded by the Privileges and Immunities Clause comes from the text of the Articles of Confederation. The passage from Article IV of the Articles of Confederation, which is widely cited as the progenitor of the Privileges and Immunities Clause, reads:

[t]he better to secure and perpetuate mutual friendship and intercourse among the people of the different States in this Union, the free inhabitants of each of the states, paupers, vagabonds and fugitives from justice excepted, shall be entitled to all privileges and immunitics of free citizens in the several States .... ${ }^{141}$

Although it is uncertain exactly who was considered a "pauper" or a "vagabond" in 18th century America, it is clear that the marginalized members of early American society were outside the Clause's protection. More recently, however, in Edwards v. California, ${ }^{142}$ the Court applied the Privileges and Immunities Clause to protect these marginalized members of society. Locating the right to travel under the Privilegcs and Immunities Clause, the Court in Edwards found that the State of California could not insulate itself from the migration of indigents. ${ }^{143}$ Thus, it is perhaps impossible to ascertain the true historical parameters of "economic unity." What is clear, however, is that any determination of the proper range of state activity must give some deference to States' control over their local economies.

With these concerns in mind, it is clear that local hiring preferences do little to threaten national economic unity or interstate commerce. Unlike state taxes and regulation that impede the flow of commerce across state lines, hiring restrictions do not seriously impede the flow of workers across States precisely because the residence requirements are not durational. Fourteenth Amendment right to travel claims have largely put an end to state laws that require, for example, a one year's residence before receiving government benefits. ${ }^{144}$ Most local hiring plans, therefore, require only present residence in order to qualify for a government job. In other words, any person who becomes

140. 334 U.S. 385 (1948).

141. ARTICLES OF CONFEDERATION art. IV, quoted in Gergen, supra note 33, at 1120.

142. 314 U.S. 160 (1941).

143. See id. at 164.

144. See, e.g., Shapiro v. Thompson, 394 U.S. 618 (1969) (holding that a state durational residence requirement for the receipt of welfare benefits violates the right to travel under the Fourteenth Amendment). One might well ask why the right to travel does not envelop the entire interstate commerce concern of the Privileges and Immunities Clause with respect to workers traveling interstate. 
a resident of a city or State can take advantage of that government's largesse. Such present residence requirements do not violate Toomer's paradigm that "a citizen of State A who ventures into State B [should enjoy] the same privileges which the citizens of State B enjoy." "As Any nonresident can travel to State B, become a resident of State B, contribute to local coffers like other residents, and thereby gain an ownership interest $\mathrm{m}$ the disposition of State B's resources. All nonresidents can therefore seek an ownership interest on equal terms; the ability to travel in interstate commerce to seek work is not impaired.

Moreover, if concerns for federalism are to leave States with some control over their local economies, then this control would be meaningless if States lacked the ability to set their own spending priorities. Indeed, there are few elements of state autonomy more fundamental than a State's control over its own funds, in no small part because of the budget constraints that exist throughout state and local government and the political wrangling necessary to pass a budget. ${ }^{146}$ Hiring preferences are compatible with national economic unity, as restricted by federalism, because they require the exercise of the spending power, and spending-more fundamentally than either state taxation or regulation-is the primary instrument for the fulfillment of local political priorities.

\section{How Is Market Participation Different from Regulation?}

Critics also attack the market participant exception on the basis that the central question posed by the doctrine-what is market participation and what is regulation-invites no principled answer. How is a court to distinguish a local government's own hiring ${ }^{147}$ from its dealings with private contractors ${ }^{148}$ from its distribution of local resources? ${ }^{149}$ Indeed, the Supreme Court justices themselves have complained that the doctrine requires judicial line-drawing based on intuition alone. ${ }^{150}$ But despite these difficulties, this central question is more easily answered

145. Toomer v. Witsell, 334 U.S. 385, 395 (1948).

146. See Varat, supra note 100 , at 532 ("Money is always a scarce resource for government.").

147. See, e.g., Garcia, 469 U.S. at 528 (1985) (finding a eity's employment practices on cityowned mass transit not immune from federal regulation); Maryland v. Wirtz, 392 U.S. 183 (1968) (finding a State's einployment practices in state-run schools and hospitals not immune from federal regulation).

148. See, e.g., White v. Massachusetts Council of Constr. Einployers, lnc., 460 U.S. 204 (1983) (holding city-funded public works contracting to be inarket participation).

149. See, e.8., Reeves, Inc. v. Stake, 447 U.S. 429 (1980) (holding that the sale of cement from state-operated cement plants constitutes market participation).

150. See Garcia, 469 U.S. at 546 (arguing that the traditional areas distinction "inevitably invitcs an unelected federal judiciary to make decisions about which state policies it favors and which ones it dislikes"); South-Central Timber Dev., Inc. v. Wunnicke, 467 U.S. 82, 102 (1984) (Rehnquist, J., dissenting) (arguing that the market participant exception requires judicial line-drawing based on intuition alone). 
under the Privileges and Immunities Clause than under the Dormant Commerce Clause. Moreover, the line between market participation and regulation is easier to discern when the criterion is public spending.

A comparison of South-Central Timber Development, Inc. $v$. Wunnicke ${ }^{151}$ with White v. Massachusetts Council of Construction Employers, Inc. ${ }^{152}$ demonstrates this central tension in the inarket participant doctrine. In South-Central Timber, the Court did not believe that the State of Alaska retained a proprietary interest in its timber that was sufficient to qualify as market participation. In holdmg that the local processing law constituted "downstream" regulation, or regulation beyond the inarket in which Alaska participated, the Court seemed to draw a line at privity of contract to delimit market participation from regulation. ${ }^{153}$ As described above, ${ }^{154}$ this holding appears to conflict with White, in which the Court allowed the city of Boston to exercise control beyond the point at which the city entered a contract.

Some commentators have likened the local hiring laws at issue in Camden and White to the downstream timber regulation in SouthCentral Timber. ${ }^{155}$ The cases are similar in that they each involve private parties making contracts with a public entity in which preferential use of local resources (workers in the former case, sawmills in the latter) is tied to the disposition of public property. Camden required that its dollars must end up in the pockets of Camden residents; Alaska required that its timber must end up in the mills of Alaskan factories. Indeed, Justice Blackmun's dissent in White states that the city's control over the contracts between construction contractors and their employees constituted "the essence of regulation." ${ }^{156}$ Does this seeining similarity dooin local preference plans? Not necessarily.

When the benchmark is individual rights rather than congressional power, the line drawn between market participation and regulation becoines less opaque. Market participation as described herein rests on a city's expenditure of public money and the resulting ownership interest of city residents. As argued above, such expenditure need not create a fundamental right and so need not implicate the Privileges and Immunities Clause. Whether a city is regulating or participating in the market under this view of market participation depends on whether the city is spending public money.

151. 467 U.S. 82 (1984).

152. 460 U.S. 204 (1983).

153. See South-Central Timber, 467 U.S. at 95.

154. See supra text accompanying note 86.

155. See, e.g., Clarke, supra note 117, at 212-14 ("A contractual stipulation tying state timber sales to local sawmilling is the same as one tying performance of local construction work to local labor.").

156. White, 460 U.S. at 219 (Blackmun, J., concurring in part and dissenting in part). 
This test is fairly easy to apply and does not give rise to the difficult line-drawing involved in distinguishing a case like White from a case like South-Central Timber. In South-Central Timber, Alaska did not spend any of its own money, while in White, Boston did: there is regulation in the former case and market participation in the latter. Similarly, if Boston or Camden had simply required all businesses operating in the city to hire locally, irrespective of their source of funds, this requirement would have been a clear case of regulation. Of course there are many other types of market intervention that a city might pursue for economic development reasons, ${ }^{157}$ some of which may involve a less clear government prerogative than does discretion over spending. But expenditures for public works clearly embody an exercise of market participatory prerogative.

One might argue, though, that the money at issue in Camden or White is simply a public resource, and therefore, no different than the timber at issue in South-Central Timber. If so, why would discrimination with respect to one resource constitute regulation, while discrimination with respect to the other constitute market participation? One rationale that could serve to distinguish market participation from regulation for purposes of the Privileges and Immunities Clause is the concept of state-created resources. It is clear from Toomer ${ }^{158}$ and SouthCentral Timber ${ }^{159}$ that the Privileges and Immunities Clause does not allow States to favor their own residents in the disposition of stateowned natural resources. But in Reeves v. Stake, ${ }^{160}$ a Dormant Commerce Clause case in which the State of South Dakota was favoring instate businesses in the sale of cement from state-run plants, the Court addressed the somewhat different scenario of state-created goods. In permitting the favoritism toward in-state business, the Court stressed that "[cement] is the end product of a complex process whereby a costly physical plant and human labor act on raw materials." 161 This analysis can be transferred to the Privileges and Immunities realm to reason that when a state or city itself has created a resource, either through its taxing power or through a state-run enterprise, it may favor its residents in the disposition of that resource. Publicly funded jobs are such a state-created resource in that cities and states cxpend staffing hours and administrative resources to conduct and monitor public contracting. Moreover, the existence of these jobs depend on tax

157. See supra Section II.B.

158. 334 U.S. 385 (1948) (holding that a State's restrictions on nonresidents' access to commercial shrimp fishing licenses violate the Privileges and Immunities Clause).

159. 467 U.S. 82 (1984) (holding that a state may not require buyers of state-owned timber to process that timber at in-state mills).

160. 447 U.S. 429 (1980).

161. Id. at 444 . 
revenue-funds that local residents have created collectively by their labor and other economic activity. Because the State's residents themselves created the resource, the right to a distribution of the resource is not "common" to citizens of all States.

\section{Cities Are Always Sovereign}

A final criticism of the market participant exception is that a city cannot be a true market participant unless it acts out of economically rational motives. But, because a government actor always acts in its own sovereign interests, commentators have argued that a State's or city's entry into markets can never be divorced from its interests as a sovereign. ${ }^{162}$ Similarly, the dissenters in Reeves $v$. Stake argued that a State cannot, in fact, act as a market participant, because it will always act out of political rather than economic motivations, and as such it would be "a pretense to equate the State with a private economic actor. ${ }^{\prime 163}$ These critics assume that to act as a market participant, a state must act like a private market actor with economically rational motivations. But such a view of market participation imports a narrow view of economic behavior into the realin of legal decision making, whereas, in fact, the State's or city's motive is irrelevant to a Privileges and Immunities analysis.

The view that cities can only be participating in markets if they act like private actors, not merely as private actors, appears in several cases and ainong several coinmentators' writings. ${ }^{164}$ Governments, it is argued, are not profit-maximizers and do not face limited resources as do private actors; furthermore, they cannot separate their political

162. See, e.g., Manheim, supra note 90, at 604-05, 608. Manheim further terms the market participant exception "oxymoronic." Id. at 608. See also, South-Central Timber, 467 U.S. at 101 (Brennan, J., concurring) (arguing that the market participant doctrine suffers from an "inherent weakness").

163. Reeves v. Stake, 447 U.S. 429, 450 (1980) (Powell, J., dissenting).

164. See, e.g., Swin Resource Sys. v. Lycoming County, 883 F.2d 245, 261-62 (3d Cir. 1989) (Gibbons, C.J., dissenting) ("Private market participants have limited resources and must ultimately seek a profit to survive. In contrast, government 'market participants' invariably seek political goals in the place of economic ends."); Manheim, supra note 90, at 607-08 ("Governments are not private persons, and do not act that way."); Note, The Market Participant Test in Dormant Commerce Clause Analysis-Protecting Protectionism?, 1985 DUKE LJ. 697, 732-33 (arguing that courts should recoguize market participation only when a state acts " $\mathrm{m}$ the form, and with the intent and impact, of an economically rational private market force"), quoted in Barton B. Clark, Give 'Em Enough Rope: States, Subdivisions, and the Market Participant Exception to the Dormant Commerce Clause, 60 U. CHI. L. REv. 615, 628 (1993); see also Wisconsin Dep't of Indus., Labor \& Human Relations v. Gould, Inc., 475 U.S. 282, 299 (1986) (holding that a local law prohibiting purchases from labor law violators could not possibly be related to state procurement constraints or to local economic needs). But see Coenen, supra note 79, at 432 ("For the state-as-trader rationale to carry persuasive force... we need not conclude that states act just like private traders."). 
from their economic motives. ${ }^{165}$ But, because economically irrational behavior does exist among private actors, this prescription amounts to nothing more than a statement of normative economic theory. And the Court has noted that the "Constitution does not require the States to subscribe to any particular economic theory." to behave like private actors would limit them to perpetuating the defects of the private market in their spending, even though a city's reason for entering the private market in the first place may have been to counteract or correct these defects. ${ }^{167}$ Moreover, if the government acts out of political motives, so what? An analysis under the Privileges and Immunities Clause looks only to the effect of government action on individual rights, not to the motivations behind that action. Thus, protectionist or economically irrational motivations should be inconsequential to a Privileges and Immunities analysis, as they will not affect the determination of whether a fundamental right has been violated.

A focus on individual rights, in fact, obviates the need to draw a line between "sovereign" and "private" or proprietary action under the Privileges and Immunities Clause. Even if a city acts as a city, using its public power for a public purpose, it is of no consequence. As long as the government spends public money, it need not offend a right under the Privileges and Immunities Clause, regardless of whether its action is classified as "sovereign" or "proprietary". Similarly, even if Garcia blurred or eliminated the line between sovereign and proprietary action, market participation under the Privileges and Immunities Clausc would not rely on a clear separation of these types of action anyway. Thus, a public-spending-based market participant exception to the Privileges and Immunities Clause not only appears workable, but also seems to rest on a firmer conceptual footing than does the current market participant exception to the Dormant Commerce Clause.

\section{The Presence of Federal and State Funding}

The preceding analysis suggests that a public spending exception to the Privileges and Immunities Clause would give rise to logically consistent categories and would be workable in practice. When a city discriminates against nonresidents, the Toomer Privileges and Immunities test asks first whether a city's action implicates a fundainental right essential to national unity. Next, the test looks to whether the city had a

165. See Reeves, 447 U.S. at 450 (Powell, J., dissenting) ("A State frequently will respond to market conditions on the basis of political rather than economic eoncerns."); see also W.C.M. Window Co. v. Bernardi, 730 F.2d 486 (7th Cir. 1984) (holding that the State of lllinois must show some data on the economic effectiveness of its local preferenee plan, either in terms of its reduction in unemployment or its cost savings to the State).

166. CTS Corp. v. Dynamics Corp. of Am., 481 U.S. 69, 92 (1987).

167. See Clarke, supra note 117 , at 210. 
substantial reason for the discriminatory program and whether its program bears a "close relation" to this reason. Currently, a city cannot escape the strictures of this Privileges and Immunities test by acting as a market participant, that is, by spending its own public money in a proprietary fashion. The exception only applies under a Dormant Commerce Clause analysis. However, as argued above, an analogous "public spending" exception could apply equally well under the Privileges and Immunities Clause. It would operate at the first level of the Toomer test, holding that individuals do not have a fundamental Privileges and Immunities right to the public funds of a city or State that is not their own. Such a public-spending-based market participant exception does not implicate any of the criticisms that have been levied against the traditional market participant exception to the Dormant Commerce Clause.

However, this analysis has assumed the simple case of a city spending its own money. In reality, public construction projects often involve some state or federal funding, funding that is not "created" solely by the residents who will benefit from a local preference plan. The presence of external funds requires a different justification for immunity under the Privileges and Immunities Clause. This Section attempts to extend the analysis of a public spending exception by exploring the following question: can cities favor their own residents when the cities are not spending their own funds? Ultimately, this Section argues that in some cases courts could find either an explicit or implicit authorization of local discrimination in the very grant of federal or state funds.

The right of a city to exercise discretion over its own funds and the lack of an individual right to another city's public funds have been central to the analysis thus far. It might appear, therefore, that when a city does not spend its own funds, but rather spends state or federal funds, a categorical public spending exception would not apply. The city might be thought not to have the right to limit access to federal or state funds because its citizens have not wholly created those federal funds. ${ }^{168}$ Under these circumstances, the market participant exception to the Dormant Commerce Clause would also seem not to apply to the extent that the market participant exception relies on the expenditure of a city's own money.

The federal or state government, in its grant of money to a city, could either authorize local preferences explicitly, prohibit them explicitly, or remain silent on the issue. There are several federal spending

168. Cf. Coenen, supra note 79, at 441 (arguing that the market participant exception to the Dormant Commerce Clause should apply only to allow local citizens to reap what they have sown), cited in Big Country Foods, Inc. v. Bd. of Educ., 952 F.2d 1173, 1180 (9th Cir. 1992). 
programs that explicitly prohibit local preferences. ${ }^{169}$ In addition, some state laws and constitutional provisions similarly prohibit local preferences. ${ }^{170}$ When a local government accepts federal or state grants with such limitations, it will have no choice but to make contracting jobs available to all workers; resident preferences will be prohibited by the terms of the grant, and no opportunity for a Privileges and Immunities problem will arise. ${ }^{171}$ The constitutional conundrums emerge, therefore, in the situations of authorization and silence.

It is unresolved in the cases whether the federal or state government can authorize a Privileges and Immunities violation. In the Commerce Clause context, the Court held in White v. Massachusetts Council of Construction Employers, Inc. that Congress had "affirmatively sanctioned" Boston's local preferences through provisions of the Urban Development Action Grants that partially funded the construction project at issue, therefore, no Dormant Commerce Clause issue was raised. ${ }^{172}$ The Court analyzed the City of Boston's use of its own funds separately from the use of federal funds, and applied the market participant inquiry only to Boston's expenditure of its own funds. With respect to the city's expenditure of federal funds, the Court held that "[w]here state or local government action is specifically authorized by Congress, it is not subject to the Commerce Clause even if it interferes with interstate commerce." 173 However, the Court in White

169. See, e.g., 49 C.F.R $§ 18.36(\mathrm{c})(2)$ (1997) (Department of Transportation requirements for grants to state and local governments); 42 C.F.R. $\$ 51$ c.504(c)(2)(ii) (1997) (Department of Health and Human Services requirement for Grants for Community Health Services); 40 C.F.R. $\S 31.36(c)(2)$ (1997) (Environmental Protection Agency requirements for grants to state and local governments); 32 C.F.R. $\S 33.36$ (c)(3)(i) (1997) (Department of Defense requirements for grants to state and local governments); 22 C.F.R $\S 135.36(\mathrm{c})(2)$ (1997) (Department of State requirements for grants to state and local governments); 13 C.F.R. $\S 143.36(\mathrm{c})(2)$ (1997) (Small Business Administration requirements for grants to state and local governments).

170. Cf. CAL. ConST. art. XI $\$ 10(\mathrm{~b})$ (prohibiting residence requirements for direct city employees, except that "such employees may be required to reside within a reasonable and specific distance of their place of employment or other designated location"). This prohibition is not tied to a particular state expenditure, but rather is a simple restriction on cities.

171. But see Big Country Foods, 952 F.2d at 1176-77 (allowing a local school district to give local bid preferences in the distribution of federally funded contracts, despite provisions in federal law that prohibited such local preferences). Plaintiff's claims with respect to the possible federal conflict and preemption issue were dismissed for lack of standing. Id.

172. See 460 U.S. 204, 213 \& n.11 (1983). The Department of Housing and Urban Development regulations that implemented these grants stipulated that cities that administer these funds are required to comply with Section 3 of the Housing and Urban Development Act of 1968, which provides, among other things, that "'to the greatest extent feasible opportunities for training and employment arising in connection with the plannning and carrying out of any project assisted under any such program be given to lower mcome persons residing in the area of sueh project...." Id. at 213-14 (quoting 24 C.F.R. $\S 135.1(a)(2)(i)$ (1982)).

173. Id. at 213 . 
specifically declined to address whether Congress could authorize local discrimination under the Privileges and Immunities Clause. ${ }^{174}$

Neither Camden nor other Privileges and Immunities cases have addressed this issue of Congressional authorization. A number of state cases prior to Camden looked at the case of local governments spending "silent" fcderal funds. These cases generally held that a high percentage of federal funding ainong a city's total public contracting expenditures rendered local discrimination more suspect because the federal funds took a project out of the city's proprietary realn. ${ }^{175}$ Salla $v$. County of Monroe, ${ }^{176}$ a New York State case, exemplifies this approach. The court in Salla squarely rejected the notion that any sort of public ownership exception exists under the Privileges and Immunities Clause and held that the $75 \%$ federal funding on the state projects at issue lessened any proprietary interest that might have weighed in favor of the constitutionality of state discrimination. ${ }^{177}$ Thus, the state courts have looked to the size of the city's proprietary or ownership interest to decide these cases.

But when the U.S. Supreme Court has reviewed city projects funded with external government money under the Privileges and Immunities Clause, it has not distinguished between federal or state money and city money. In Camden, the Court looked at city projects funded with money that the city merely "administer[ed],",178 which presumably included some federal or state money. Still, Camden was not terribly helpful in answering the question left open by White as to whether Congress can authorize a Privileges and Immunities violation. The Court in Camden declined to apply a market participant exception to the Privileges and Immunities Clause; ${ }^{179}$ therefore, the source of funding did not enter into the Court's analysis. It is unclear whether the Court found that the source of funding was immaterial to a Privileges and Immunities analysis in general, or simply that the source of funds was immaterial to that holding given that no market participant exception applied. In either case, the Court did not distinguish the different

174. See id. at $215 \mathrm{nn} .1$ \& 12 (Blackmun, J., concurring in part and dissenting in part).

175. See, e.g., Opinion of the Justices to the Senate, 469 N.E.2d 821,825 n.8 (Mass. 1984) (holding that the State's proprietary interest in projects, which weighed in favor of the constitutionality of the proposed state resident hiring requirements, would be reduced if a project were funded only in part with state funds); Neshaminy Constructors, Inc. v. Krause, 437 A.2d 733, 737 (N.J. 1981), modified on other grounds, 453 A.2d 1359 (N.J. 1982) (holding that the 80\% federal funding of state construction contracts made the state interest too attenuated to take the contracts out of the purview of the Privileges and Immunities Clause); Laborers Local Union No. 374 v. Felton Constr. Co., 654 P.2d 67, 71 (Wash. 1982) (holding that the 75\% federal funding on a state project left the State with insufficient justification for its discrimination against nonresidents).

176. 399 N.E.2d 909, 914-15 (N.Y. 1979).

177. See id.

178. United Bldg. \& Constr. Trades Council v. Mayor of Camden, 465 U.S. 208, 214 (1984).

179. See id. at 219-20. 
sources of funds, and subsequent Privileges and Immunities cases have similarly failed to elucidate this issue. ${ }^{180}$

Camden and the state cases seem driven by a misconception that the presence of federal money is only relevant in determining whether a city is acting as a proprietor. The proprietor/regulator distinction is critical to the traditional market participant exception. Although the effect of federal or state funding on the ability of a city to claim proprietary immunity may be critical to the Dormant Commerce Clause, the Privileges and Immunities Clause does not rely so heavily on the character and form of city action. Rather, the focus of the Privileges - and Immunities Clause is individual rights, and the critical question is whether public funds spent-federal, state, or local-give rise to a fundamental right protected by the Privileges and Immunities Clause. Thus, the presence of state or federal money might sigual the failure of the market participant exception in the Dormant Commerce Clause context, ${ }^{181}$ but need not similarly doom the exception under the Privileges and Immunities Clause. When federal funds are present, the proper question is whether the federal spending inplicates a right protected by the Clause.

With regard to public contracting, Toomer, Hicklin, and Camden indicate that the Privileges and Immunities Clause protects rights fundamental to national unity, notably the right to pursue a common calling. As described above, employment funded by public money does not necessarily give rise to a fundamental right; indeed, the focus of this Comment thus far has been to argue that limiting local funds to local residents does not inplicate national unity interests in derogation of the Privileges and Immunities Clause. Accordingly, with respect to federal or state funds spent by a city, the Privileges and Immunities analysis must ask whether there is a national unity interest in federal- or statefunded employment that the Privileges and Immunities Clause protects.

180. See, e.g., Salem Blue Collar Workers Ass'n v. Salem, 33 F.3d 265, 269 (3d Cir. 1994) (addressing direct public employment); W.C.M. Window Co. v. Bernardi, 730 F.2d 486, 495, 496-98 (7th Cir. 1984) (addressing the source of funds issue under the Commerce Clause but not under the Privileges and Immunities Clause); 1st Westco Corp. v. Sch. Dist., 811 F. Supp. 204, 208 (E.D. Pa. 1993) (addressing publicly funded projects, but not identifying the source of funds); Int'1 Org. of Masters, Mates \& Pilots v. Andrews, 626 F. Supp. 1271, 1283-84 (D. Alaska 1986) (refcrring to state preferences on a state-owned and funded enterprise); State v. Antonich, 694 P.2d 60, 62 (Wyo. 1985) (referring to government projects made possible by citizens contributions to the public treasury).

181. But see Big Country Foods, Inc. v. Bd. of Educ., 952 F.2d 1173, 1179-80 (9th Cir. 1992) (holding that a school district's activities as a purchaser qualify it as a market participant, even though all the money for the purchasing came from the federal government); Swin Resource Systems v. Lycoming County, 883 F.2d 245, 250 (3d Cir. 1939) (holding that a county would not violate the Commerce Clause if it restrictcd access to a local dump, even though the dump was on federal land and funded with federal money). In both cases, the local govcrnment's operation of the public project, even in the absence of actual funding, was enough to qualify as market participation. 
Stated differently, do all U.S. citizens have a Privileges and Immunities right to federal or state spending?

It might seem that each U.S. resident has an equal right to federal funds; under the rationale advanced herein, each person has contributed toward and helped create these funds. Because individuals hold Privileges and Immunities rights against state discrimination, Congressional authorization of such discrimination would seem to be irrelevant. Congress can authorize Dormant Commerce Clause violations only because the Commerce Clause is an affirmative grant of power to Congress through which a restraint on state action is implied. Accordingly, Congress can relinquish this power as it chooses. The Privileges and Immunities Clause, however, is not a grant of power to Congress, but rather a grant of rights to individuals and a direct restraint on the states. Like any other individual right, it is presumably immune from Congressional curtailment unless Congress can meet the appropriate form of judicial scrutiny.

But does it make sense to talk about a Privileges and Immunities right in the disbursement of federal funds? The Privileges and Immunities Clause does not protect against all instances of economic protectionism. One important nuance of Privileges and Immunities doctrine is that in the case of city preference plans, in-state but out-of-city residents fail to state a claim under the Privileges and Immunities Clause. ${ }^{182}$ Thus, a city plan must affect out-of-state citizens to constitute a Privileges and Immunities violation. It may seem incongruous that in-state residents do not have standing to claim a Privileges and Immunities violation, given that the core values that underlie the Clause-values of market access and the right to pursue a coinmon calling-are potentially offended to an equal degree when only in-state residents are affected. However, courts generally address the rights of in-state residents by appealing to a political-process rationale. ${ }^{183} \mathrm{In}$ state residents have access to their state legislatures and other political channels, through which they can attempt to alleviate the discrimination by a change in state policy; nonresidents, however, have no similar means of redress. The courts step in not only to protect these nonresidents, but also to prevent potential state-to-state retaliation. ${ }^{184}$

This in-state but out-of-city resident scenario provides a good analog for the interplay of rights that is at work in the case of federal funds. While each U.S. resident is a member of the political community

182. See, e.g., Camden, 465 U.S. at 217 (holding that "the disadvantaged [in-state] New Jersey residents have no claim under the Privileges and Immunities Clause").

183. See, e.g., id. at 217 (citing Austin v. New Hampshire, 420 U.S. 656, 662 (1975)).

184. See Tooner v. Witsell, 334 U.S. 385, 395 (1948) ("For the protection of such equality the citizen of State $A$ was not to be restricted to the uncertain remedies afforded by diplomatic processes and official retaliation."). 
that created the federal funds at issue on these city public works projects, this membership actually hurts U.S. residents more than it helps them in seeking a Privileges and Immunities remedy. In the same way that a worker cannot bring a Privileges and Immunities challenge against her own city or her own State, so too can she not bring a claim against the federal government. In each case, the worker can rely on political channels as a means of redress.

Of course, aggrieved workers would not truly bring a Privileges and Immunities claim against the federal government, but rather against the city that allegedly "inisuses" federal funds. Nevertheless, that worker must make the claim that she had a right to those federal funds that the city has denied her. And what is the source of this right? It does not appear to exist under the Privileges and Immnnities Clause, which provides a remedy against discrimination by other States rather than insures U.S. residents' access to federal funds. And since U.S. residents can very well persuade Congress to prohibit local preferences explicitly, as evidenced by the several federal administrative schemes with such prohibitions, ${ }^{185}$ these residents need not rely on the Privileges and Immunities Clause for a remedy.

The only right that individuals have in disbursements of federal funds is the baseline Fifth Amendment right to equal treatment. ${ }^{186}$ Indeed, no citizen has a right to government spending in general, unless that citizen arguably falls within a category of persons entitled to a legislatively created benefit. Citizens have the right only to be free of invidious discrimination, such as race or gender discrimination, in the distribution of government benefits, ${ }^{187}$ but state residency is not such an invidious classification. ${ }^{188}$ Thus, the federal government could allocate benefits to citizens of one State but not another. By siting military bases, granting agricultural subsidies, or funding infrastructure projects, the federal government regularly selects particular States to benefit disproportionately froin federal spending.

Because this right in federal funds ceases to be a Privileges and Immunities right, it therefore appears that Congress can, indeed,

185. See supra note 169.

186. See Buckley v. Valeo, 424 U.S. 1, 93 (1976) (holding that "[e]qual protection analysis in the Fifth Amendment area is the same as that under the Fourteenth Amendment").

187. See Adarand Constructors, Inc. v. Pena, 515 U.S. 200, 227 (1994) (holding that "all racial classifications, imposed by whatever federal, state, or local government actor, must be analyzed by a reviewing court under strict scrutiny").

188. See Laborers Local Union No. 374 v. Felton Constr. Co., 654 P.2d 67, 72 (Wash. 1982) (holding that "residency is not a suspect category"); see also Shapiro v. Thompson, 394 U.S. 618, 638 n.21 (1969) (holding that state waiting periods for government benefits violate the Fourteenth Amendment, but adding that " $[w]$ imply no view of the validity of waiting-period or residence requirements determining eligibility to vote, eligibility for tuition-free education, to obtain a license to practice a profession, to hunt or fish, and so forth"). 
authorize local discrimination. Such authorization would not be in derogation of a Privileges and Immunities right if that right only exists to the degree that one enjoys a Congressionally created benefit in the first place. This analysis also has important ramifications for the case of "silent" federal funds. The very delegation of spending authority to 10cal governments suggests a Congressional awareness that these local governments will use the money for local needs. Indeed, if every local government in the United States receives some amount of federal money, whether directly or through state subventions, each citizen will have the benefit of his or her own local government's share of this federal spending. However, the share given to another local government is intended for the benefit of that other locality. Congress and the various administrative agencies have the power to prohibit residence discrimination in the use of federal funds, ${ }^{189}$ and can do so if they see fit. Thus, by distributing money to States and cities for expenditures on local needs, Congress can be seen to have given tacit approval to local preferences. ${ }^{190}$ Again, the presence of federal funds is not damning to a local preference plan, as the relevant question is whether individuals have a right to those federal funds.

Under this individual rights framework, it also appears that there is no Privileges and Immunities right in state spending. A worker might bring a Privileges and Immunities challenge either against a city in her own State or against a city in another State. For claims against cities in another State, state nonresidents lack a common claim to the disposition of another State's funds, just as individuals who do not reside in a particular city do not have a right to employment created by that city's funds. The argument with respect to state funds would be the same as the argument with respect to city funds presented above. Thus, a city public works prograin that uses state funds does not give rise to an infringement of the right to pursue a common calling for out-of-state individuals, and so creates no Privileges and Immunities violation for these individuals. For the other type of potential clains-claims against one's own State-in-state but out-of-city residents fail to state a claim under the Privileges and Iminunities Clause. ${ }^{191}$ An in-state resident certamly has a clain to the disposition of state funds that perhaps a city should not be able to restrict, but these in-state residents must look

189. See supra note 169.

190. Cf. Big Country Foods, Inc. v. Bd. of Educ., 952 F.2d 1173, 1179-80 (9th Cir. 1992) (arguing that a school district's activities as a purchaser qualify it as a market participant, even though all the money for the purchasing came from the federal government); Salla v. County of Monroe, 399 N.E.2d 909, 916 n.3 (N.Y. 1979) (Gabrielli, J., dissenting) (arguing in the Commerce Clause context that federal funding does not threaten market participant immunity in the absence of explicit Congressional prohibition).

191. See supra note 182 and accompanying text. 
somewhere other than the Privileges and Immunities Clause for a remedy. Thus, even if the use of state funds by a city might undermine its claim to market participant status under the Dormant Commerce Clause, it has no effect under the Privileges and Immunities Clause.

When one views the Privileges and Immunities Clause outside of the framework of "proprietary interests," a framework borrowed from the market participation logic under the Dormant Commerce Clause, and instead focuses on individual rights in public spending, it becomes evident that potential nonresident Privileges and Immunities claims should be more narrow than under current law. Indeed, it appears that the right to pursue a common calling under the Privileges and Immunities Clause does not necessarily extend to jobs created by public funds, whether federal, state, or local.

\section{CONCLUSION}

Government intrusion on individual rights should never be taken lightly. This caveat may be particularly important in the case of the Privileges and Immunities Clause, which provides one of the few affirmative grants of rights in the original text of the Constitution. But like all rights, individual privileges and immunities are not boundless. The boundaries to these rights grow out of the contrary rights of cities to form separate and distinct political communities, and to channel their own resources to the residents who have created those resources. A public-spending-based market participant exception to the Privileges and Immunities Clause accommodates these desires without offending the underlying principles of interstate comity that motivated the Framers of the Clause. Moreover, the public spending exception provides a useful framework for analyzing the more difficult cases that involve federal funding or non-monetary benefits. To accept local hiring preferences, it is true, courts must develop a stomach for some degree of local economic protectionism. But, given the traditional focus of the Privileges and Immunities Clause on state taxation and regulation, it appears that earmarking local money for local residents does not constitute protectionism in the traditional sense. And, ultimately, allowing such behavior means allowing local governments the flexibility to respond to pressing local economic realities. 